\title{
Effects of climate change on soil carbon and nitrogen storage in the US Great Plains
}

\author{
R.F. Follett, C.E. Stewart, E.G. Pruessner, and J.M. Kimble
}

\begin{abstract}
Soils of the US Great Plains contain enormous stocks of soil organic carbon (SOC) and soil organic nitrogen (SON) that are vulnerable to predicted climate and land use change. Climate change scenarios predict a $2.2^{\circ} \mathrm{C}$ to $3.6^{\circ} \mathrm{C}\left(4^{\circ} \mathrm{F}\right.$ to $\left.6.5^{\circ} \mathrm{F}\right)$ increase and more variability in precipitation across most of the United States. This study quantifies management effects (native grassland, Conservation Reserve Program [CRP], and cropped) on SOC and SON stocks across the region and assessed soil variables (soil texture, cation exchange capacity, and others) and climatic drivers (precipitation and temperature) to predict future changes in carbon (C) and nitrogen $(\mathrm{N})$ stocks. Across all sites, cropped land had significantly lower $\mathrm{C}$ and $\mathrm{N}$ stocks in the 0 to $5 \mathrm{~cm}$ ( 0 to 2 in) and 0 to $10 \mathrm{~cm}$ (0 to 3.9 in) depths than native sites, while CRP sites were intermediate. Mean annual temperature (MAT), the ratio of mean annual precipitation to potential evapotranspiration (MAP:PET), soil bulk density (BD), and clay content were important covariates for SOC and SON stocks within land use. Soil C and $\mathrm{N}$ stocks under all three land uses were strongly negatively related to MAT and positively related to MAP:PET, suggesting that they are equally vulnerable to increased temperature and decreasing water availability. Based on these empirical relationships, a $1^{\circ} \mathrm{C}\left(1.8^{\circ} \mathrm{F}\right)$ increase in MAT could cause a loss of $486 \mathrm{Tg}$ SOC (536 million tn) and a loss of $180 \mathrm{~kg} \mathrm{SON} \mathrm{ha}^{-1}$ $\left(160 \mathrm{lb} \mathrm{SON} \mathrm{ac}^{-1}\right)$ from the top $10 \mathrm{~cm}$ (3.9 in) of soil over 30 years, but the decrease will be mediated by water availability (MAP:PET). Combined, increased temperature and conversion from CRP to cropland could decrease the existing SOC sink, but improved soil management and increased water availability may help offset these losses in the US Great Plains.
\end{abstract}

Key words: climate change-mean annual temperature-potential evapotranspiration-soil carbon-soil nitrogen

\begin{abstract}
Soils in the Great Plains are strongly affected by climatic gradients in temperature and moisture and contain large stocks of soil organic carbon (SOC) and soil organic nitrogen (SON). Maintaining carbon $(\mathrm{C})$ and nitrogen $(\mathrm{N})$ stocks within the soils of this vast region requires a balance between plant primary productivity and decomposition, both of which are affected by carbon dioxide $\left(\mathrm{CO}_{2}\right)$, temperature, and soil moisture, and are modified by soil texture (Dijkstra and Morgan 2012). Vegetation drives maximum $\mathrm{C}$ input to the soil and varies across ecosystem biomes, primarily with moisture gradients (Del Grosso et al. 2008; Jobbagy and Jackson 2000). Consequently, SOC and SON stocks are also highly related to temperature and precipitation gradients (Jenny 1941; Burke et al. 1989; McCulley et al. 2009). Temperature and moisture serve
\end{abstract}

efficiency. The combined effects of increased temperature and $\mathrm{CO}_{2}$, when selected for different plant functional responses, indicated that warming boosted growth of grasses with the $\mathrm{C} 4$ photosynthetic pathway, while elevated $\mathrm{CO}_{2}$ mostly favored growth of $\mathrm{C} 3$ grasses. Together, these effects resulted in greater $\mathrm{C} 4$ aboveground biomass in years with limiting water. Their results suggest that "in a warmer, $\mathrm{CO}_{2}$-enriched world, both soil water content and productivity in semiarid grasslands may be higher than previously expected." Based on their data, SOC sequestration on the Great Plains might increase. However, these initial plant responses to changes in temperature and $\mathrm{CO}_{2}$ observed by Morgan et al. (2011) may not reflect long-term SOC dynamics since increased plant $\mathrm{C}$ inputs can lead to increased decomposition (Carrillo et al. 2011).

Conservation management practices, such as the Conservation Reserve Program (CRP), encourage marginal farmland to be planted into perennial grasses and have significantly increased SOC storage in the top 0 to $30 \mathrm{~cm}$ (0 to 11.8 in) (Follett et al. 2001; Liebeg et al. 2008). In the United States, the CRP program has had 400,000 participants - most of whom are farmers and ranchers-and covers about 13.6 Mha (33.7 million ac) (figure 1). Results from across 13 states and 14 soil series in the US Great Plains showed CRP to sequester SOC at a rate of

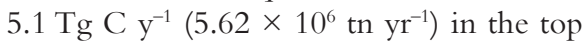
$20 \mathrm{~cm}$ (0 to $7.9 \mathrm{in})$ over 5.6 Mha (13.8 million ac) (Follett et al. 2001). In an expanded study that included 21 soil series across 19 states representing 9 Mha (22.2 million ac) of native, cropped, and revegetated (or CRP) treatments (Follett 2009; Follett et al. 2009a), $28 \%$ and $23 \%$ of the SOC in the $100 \mathrm{~cm}$ (39.4 in) profile - of native and cropped land, respectively - was located in the top 0 to 10 $\mathrm{cm}$ (0 to 3.9 in). These lands represent a considerable stock of soil $\mathrm{C}$ and $\mathrm{N}$, which will be affected by future climate change.

To better protect SOM in the face of climate change, it is highly important to

Ronald F. Follett and Catherine E. Stewart are soil scientists in the Soil Plant Nutrient Research Unit of USDA Agricultural Research Service in Fort Collins, Colorado. Elizabeth G. Pruessner is a biological science technician at USDA Agricultural Research Service in Fort Collins, Colorado. John $\mathrm{M}$. Kimble is a retired soil scientist at USDA Natural Resources Conservation Service in Lincoln, Nebraska. 


\section{Figure 1}

Cumulative acreage enrolled in the Conservation Reserve Program (CRP) as of September 20, 2009 (USDA FSA 2009). To convert to hectares, multiply the number of acres by 0.4046.

Legend

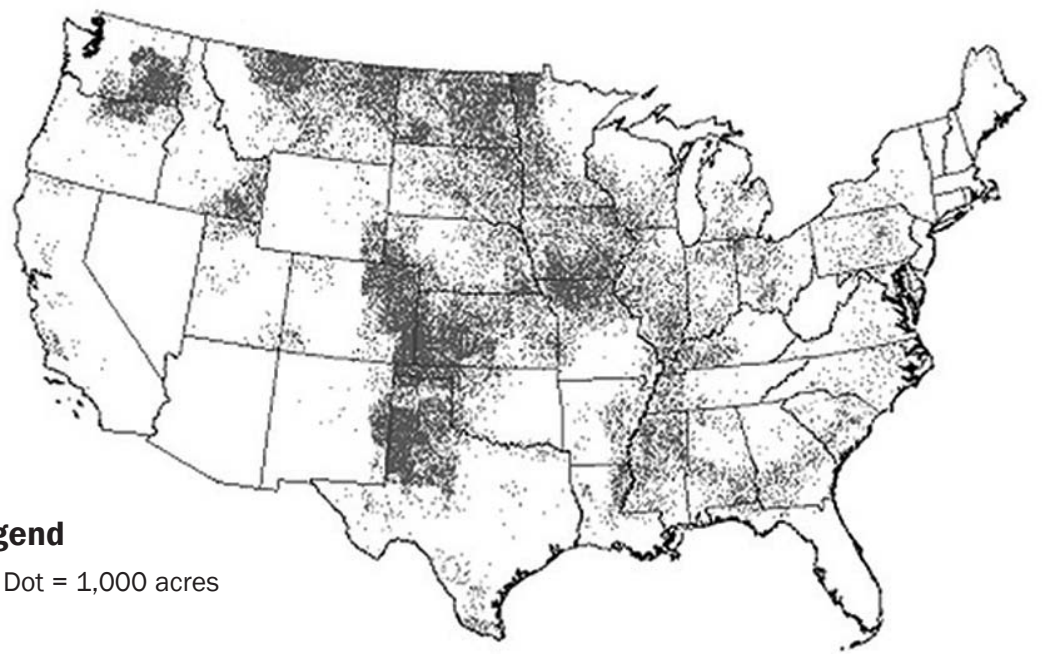

Total: $\mathbf{3 3 . 7}$ million acres

\section{Figure 2}

Study sites and historic natural grasslands (Kuchler 1985). The mean annual precipitation increases from the shortgrass prairie in the west to the tallgrass prairie in the east. The mean annual temperature increases from the north to the south.

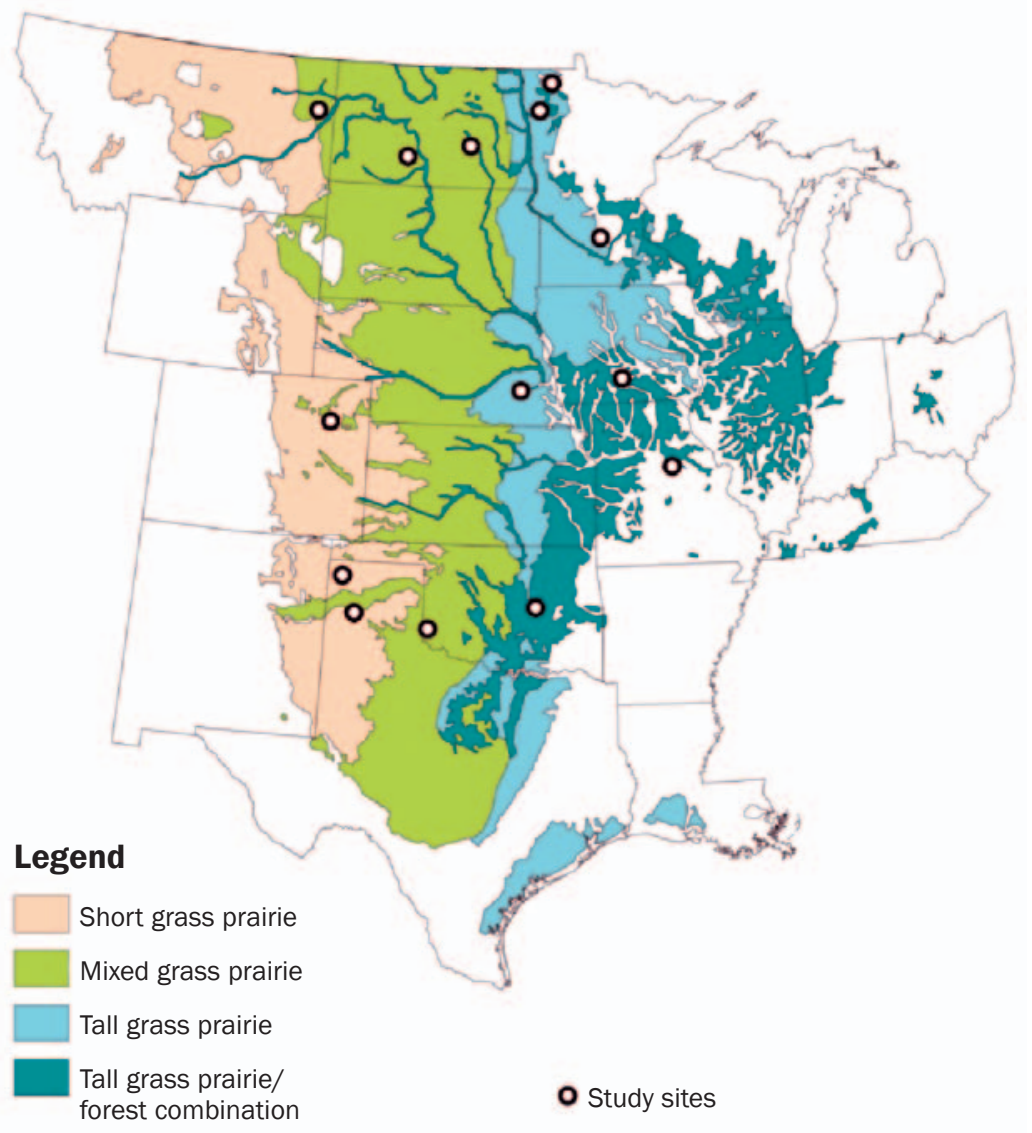

improve our understanding of the interactions between climatic factors, soil properties, and land use practices. In this analysis, we use SOC and SON as an integrative measure of productivity and decomposition across welldocumented gradients in temperature and precipitation consisting of matching pedons under native grassland, CRP, and cropland at 14 sites in the Great Plains (Leavitt et al. 2007; Follett et al. 2001, 2004). Previous research at these sites found a strong plantderived signal from current vegetation in the top 0 to $10 \mathrm{~cm}$ (0 to 3.9 in) using $\delta^{13} \mathrm{C}$ and a modern ${ }^{14} \mathrm{C}$ soil age (Follett et al. 2001; Leavitt et al. 2007). Data from the entire soil profile of the undisturbed sites have been used to reconstruct paleoclimate (Leavitt et al. 2007) and the distribution of C3 and C4 grasses (Follett et al. 2004). Here, we expand the previous analysis to explicitly include both climatic factors (precipitation and temperature) as well as soil variables (soil texture, cation exchange capacity, and others) to quantify management effects and to assess soil and climatic drivers on SOC and SON stocks across the region. Land uses with greater plant productivity and lower rates of plant and SOM decomposition, such as CRP and native systems, will have greater SOC and SON stocks compared to cultivated systems. We then developed empirical relationships between SOC and SON stocks and used 30-year climate data to estimate potential general effects of climate change on these important stocks.

\section{Materials and Methods}

Field Sampling. Fourteen sites were selected across the Great Plains representing a broad range of climatic variables and soil properties (figure 2) (Leavitt et al. 2007; Follett et al. 2001, 2004). Sampling sites were selected based on major geomorphic units (soil series) with similar slope and aspect. Soils were collected from the 0 to $5 \mathrm{~cm}$ (0 to 2 in) and 5 to $10 \mathrm{~cm}$ (2 to 3.9 in) depths (the A1 [topsoil] and A2 horizons [native land use] or the Ap1 [plowed topsoil] and Ap2 horizons [CRP and cropped land use]) and subsequent depths by genetic horizon to about 2 $\mathrm{m}(6.6 \mathrm{ft})$. The stock of SOC within 10 to 30 $\mathrm{cm}$ (3.9 to $11.8 \mathrm{in}$ ) depth was based upon the SOC stock within genetic soil horizon or horizons as appropriate within 10 to $30 \mathrm{~cm}$. The focus of this study is on SOC stocks at depths $<30 \mathrm{~cm}$ since these shallower depths better respond to management (Follett 2009; 


\section{Table 1}

Climate, soil, and management (years in Conservation Reserve Program) for the 14 sites sampled within the US Great Plains.

\begin{tabular}{|c|c|c|c|c|c|c|c|c|}
\hline Site & $\begin{array}{l}\text { Years } \\
\text { in CRP }\end{array}$ & $\begin{array}{l}\operatorname{MAX} \\
\left({ }^{\circ} \mathbf{C}\right)\end{array}$ & $\begin{array}{l}\text { MAT } \\
\left({ }^{\circ} \mathbf{C}\right)\end{array}$ & $\begin{array}{l}\text { MAP } \\
(\mathbf{m m})\end{array}$ & $\begin{array}{l}\text { PET } \\
(\mathrm{mm})\end{array}$ & $\begin{array}{l}\text { MAP:PET } \\
\text { ratio }\end{array}$ & $\begin{array}{l}\text { Surface } \\
\text { texture }\end{array}$ & Taxonomic classification \\
\hline Bushland, Texas & 8 & 21.3 & 13.9 & 501 & 1,232 & 0.41 & Clay loam & $\begin{array}{l}\text { Fine, mixed, superactive, thermic Torrertic } \\
\text { Paleustolls }\end{array}$ \\
\hline Vinson, Oklahoma & 10 & 23.8 & 16.2 & 665 & 1,189 & 0.56 & Loam & $\begin{array}{l}\text { Fine-loamy, mixed, superactive, thermic } \\
\text { Typic Argiustolls }\end{array}$ \\
\hline Akron, Colorado & 6 & 17.2 & 9.0 & 421 & 697 & 0.61 & Silt loam & $\begin{array}{l}\text { Fine-loamy, smectitic, mesic Aridic } \\
\text { Argiustolls }\end{array}$ \\
\hline Lincoln, Nebraska & 6 & 17.3 & 11.1 & 738 & 912 & 0.81 & Silt loam & Fine, smectitic, mesic Pachic Argiustolls \\
\hline Columbia, Missouri & 7 & 18.3 & 12.2 & 1,023 & 906 & 1.13 & Silt loam & $\begin{array}{l}\text { Fine, smectitic, mesic Aeric Vertic } \\
\text { Epiaqualfs }\end{array}$ \\
\hline Sidney, Montana & 5 & 14.3 & 6.9 & 364 & 576 & 0.63 & Loam & $\begin{array}{l}\text { Fine-silty, mixed, superactive, frigid Typic } \\
\text { Haplustolls }\end{array}$ \\
\hline Mandan, North Dakota & 10 & 11.9 & 5.5 & 433 & 577 & 0.75 & Loam & $\begin{array}{l}\text { Fine-loamy, mixed, superactive, frigid } \\
\text { Typic Argiustolls }\end{array}$ \\
\hline Medina, North Dakota & 10 & 10.8 & 4.3 & 434 & 529 & 0.82 & Loam & $\begin{array}{l}\text { Fine-loamy, mixed, superactive, frigid } \\
\text { Calcic Hapludolls }\end{array}$ \\
\hline Dorothy, Minnesota & 7 & 9.9 & 3.7 & 585 & 565 & 1.04 & Loamy sand & Sandy, mixed, frigid Aquic Hapludolls \\
\hline Roseau, Minnesota & 7 & 8.2 & 2.6 & 527 & 539 & 0.98 & Loam & $\begin{array}{l}\text { Coarse-loamy, mixed, superactive, frigid } \\
\text { Typic Calciaquolls }\end{array}$ \\
\hline
\end{tabular}

Notes: Maximum (MAX) and mean (MAT) annual temperatures and mean annual precipitation (MAP) values for locations are from the nearest weather station within each state as reported by the National Climatic Data Center (2002). PET = potential evapotranspiration.

Follett et al. 2009b) and likely climate during possible decadal time intervals. Data on SOC stocks below $30 \mathrm{~cm}$ for these same sites and methods used for their determination are previously published (Follett et al. 2009a).

For each site, a native prairie, CRP, and cropped land use was chosen with each on the same soil series with similar slope and aspect, thus allowing soil pits to be sampled and compared. Soil, climate parameters, and years each site had been in the CRP when sampled are in table 1. Land use management and vegetation components are given in table 2. Simple statistics for climate and selected soil properties across the 14 sites are in table 3. Table 3 includes both standard deviations and coefficients of variation for the climatic and soil properties. The utility of the coefficient of variation is its independence of the magnitude of the data (Reimans et al. 2008; Snedecor and Cochran 1967). Values for mean annual temperature (MAT) and mean annual precipitation (MAP) that we used are from weather station data at or very near the experimental sites based upon latitude and longitude and from 30-year records of weather data (NCDC 2002). Values for potential evapotranspiration (PET) are from Vörösmarty et al. (1998).

Laboratory Analyses. At each site, land use and, for every soil layer, bulk densities (BD) were determined using clods collected from representative soil material excavated from the face of the soil pits. Standardized laboratory procedures were used to measure BD (NRCS 2004; Soil Survey Laboratory method $3 \mathrm{~B}$ ), including desorption to $33 \mathrm{kPa}$ $(1 / 3$ bar $)$. Soil clods were cut from the excavated soil material to a suitable size (average of about $\left.210 \pm 70 \mathrm{~cm}^{3}\left[12.8 \pm 4.3 \mathrm{in}^{3}\right]\right)$ using a butcher knife, coated immediately with Saran F310, hung on a clothes line to dry, then placed in chambered boxes for transport to the laboratory. This method not only allowed a relatively undisturbed sample to be obtained from the field but also protected the samples during transport and for subsequent laboratory measurements. In the laboratory and following desorption to $33 \mathrm{kPa}$, the clod was weighed in air to measure mass and in water to measure its volume and next dried at $110^{\circ} \mathrm{C}\left(230^{\circ} \mathrm{F}\right)$ with its mass and volume again determined. A correction is made for mass and volume of rock fragments and the Saran F310 coating with the $\mathrm{BD}$ value reported for $<2 \mathrm{~mm}$ $(<0.079$ in) soil fabric (NRCS 2004; Soil Survey Laboratory method 3B1). Blake and Hartge (1986) discuss a concern that the clod method of measuring $\mathrm{BD}$, as they describe it, does not adequately account for interclod spaces and thus gives higher bulk-density values than do other methods. This concern is addressed by the field collection method wherein clods are cut and trimmed out of excavated representative soil matrix material. Soils sampled across the 14 sites studied, ranging from loamy sand to clay loam, are grassland soils and inherently contain no or very few gravel or rock fragments. The soil surface texture and taxonomic classification at each site are included in table 1 (Follett et al. 2001, 2009a). The BD values obtained were used to convert data from a weight to a volume basis $\left(\mathrm{g} \mathrm{cm}^{3}\right)$ as required to calculate the mass of soil in a unit volume of soil depth and thence to calculate amounts of SOC and SON per unit area for the soil layer sampled. 
Table 2

Management treatments and plant cover for the cropped, Conservation Reserve Program (CRP), and native prairie land uses at each of 14 sites within the US Great Plains.

\begin{tabular}{|c|c|c|c|}
\hline Site & Cropped (tillage) & CRP & Native prairie \\
\hline Bushland, Texas & CT wheat/fallow & Plains bluestem & $\begin{array}{l}\text { Blue grama, blue stem, western wheat grass, buffalo grass, } \\
\text { prickly pear }\end{array}$ \\
\hline Dalhart, Texas & CT sorghum/wheat & Plains bluestem & $\begin{array}{l}\text { Sand bluestem, side oats grama, sand drop seed, yucca, } \\
\text { squirrel tail bottle brush, sand sedge, sage }\end{array}$ \\
\hline Vinson, Oklahoma & CT cotton/wheat & Bermuda grass & $\begin{array}{l}\text { Little bluestem, buffalo grass, side oats grama, hairy } \\
\text { grama, thistles, threeawn, sandburs, mesquite, woolly } \\
\text { locoweed }\end{array}$ \\
\hline Boley, Oklahoma & CT winter wheat & Broomsedge, annual weeds & $\begin{array}{l}\text { Big bluestem, little bluestem, splitbeard bluestem, indian- } \\
\text { grass, broomsedge, western ragweed, post oak tree, wing } \\
\text { tipped elm tree, scribers panicum, wood sorrel. }\end{array}$ \\
\hline Akron, Colorado & CT wheat/fallow & $\begin{array}{l}\text { Bromegrass, } \\
\text { intermediate wheat grass }\end{array}$ & $\begin{array}{l}\text { Buffalo grass, blue grama, sunsedge, scarlet globemallow, } \\
\text { mare's tail, slim flower, scurf pea, bottle brush squirrel tail, } \\
\text { cutleaf evening primrose, curly cup gumweed }\end{array}$ \\
\hline Lincoln, Nebraska & CT wheat/fallow & Mostly bromegrass & Bromegrass, lettuce, snow on the mountain, hoary vervain \\
\hline Columbia, Missouri & NT double crop soybeans & Orchard grass, alfalfa & $\begin{array}{l}\text { Indiangrass, wild rose, ironweed, goldenrod, wild } \\
\text { strawberry, cowpea }\end{array}$ \\
\hline Indianola, lowa & CT corn/soybean & Bromegrass, clover, alfalfa & $\begin{array}{l}\text { Cool season grasses, wild rose, indiangrass, golden rod, } \\
\text { partridge pea }\end{array}$ \\
\hline Glencoe, Minnesota & CT peas (corn/soybeans) & Orchard, bromegrass, alfalfa & Cool season grasses and forbs in abundance \\
\hline Sidney, Montana & CT spring wheat/barley & Bromegrass & $\begin{array}{l}\text { Cool season grasses, prairie junegrass, sandburg } \\
\text { bluestem, needle \& threadgrass, green needlegrass, } \\
\text { white milkwort, harebell, yellow flower salsify, purple } \\
\text { milkvetch, breadroot scurfpea, prairie rose, prairie } \\
\text { coneflower, dandelion, saltbrush, clubmoss, wooly Indian } \\
\text { wheat, western yarrow }\end{array}$ \\
\hline Mandan, North Dakota & CT wheat & Intermediate wheat grass & $\begin{array}{l}\text { Little bluestem, blue grama, scurfpea, red threeawn, } \\
\text { prairie rose, prairie coneflower, Missouri goldenrod, } \\
\text { dotted gayflower, wild cool season grasses, onion, } \\
\text { fringed sagewort, leadplant, purple coneflower }\end{array}$ \\
\hline Medina, North Dakota & CT clover/barley/wheat & Alfalfa, bromegrass & $\begin{array}{l}\text { Cool season grasses, curlycup gumweed, black sampson, } \\
\text { yellow sweet clover, western snowberry, stiff goldenrod, } \\
\text { rush skeleton plant, white sweet, clover, cudweed } \\
\text { sagewort, silverleaf scurfpea }\end{array}$ \\
\hline Dorothy, Minnesota & CT barley/corn & Bromegrass & Cool season grasses, yellow jack in the pulpit \\
\hline Roseau, Minnesota & CT wheat & Alfalfa, timothy & Cool season grass, grazed pasture with trees \\
\hline
\end{tabular}

Notes: $\mathrm{CT}=$ conventional tillage. $\mathrm{NT}=$ no-tillage.

\section{Table 3}

Simple statistics for climate and selected soil properties at 14 sites (o to $10 \mathrm{~cm}$ depth) across the US Great Plains.

\begin{tabular}{lccccc}
\hline Variable & Mean & $\begin{array}{l}\text { Standard } \\
\text { deviation }\end{array}$ & $\begin{array}{l}\text { Coefficient of } \\
\text { variation (\%) }\end{array}$ & Minimum & Maximum \\
\hline MAT $\left({ }^{\circ} \mathrm{C}\right)$ & 9.4 & 4.5 & 48 & 2.6 & 16.9 \\
MAP $(\mathrm{mm})$ & 633 & 221 & 35 & 364 & 1,074 \\
PET $(\mathrm{mm})$ & 811 & 246 & 30 & 529 & 1,232 \\
MAP:PET $(\mathrm{mm}: \mathrm{mm})$ & 0.81 & 0.23 & 28 & 0.41 & 1.13 \\
BD $\left(\mathrm{g} \mathrm{cm}^{-3}\right)$ & 1.15 & 0.24 & 21 & 0.66 & 1.58 \\
Sand $(\%)$ & 36.1 & 26.4 & 73 & 3.1 & 90.2 \\
Clay $(\%)$ & 20.6 & 7.9 & 38 & 3.8 & 30.8 \\
CEC $\left(\mathrm{cmol} \mathrm{kg}{ }^{-1}\right)$ & 21.1 & 10.2 & 48 & 4.9 & 40.7 \\
Carbonate $(\%)$ & 0.93 & 3.18 & 343 & 0.00 & 14.00 \\
\hline
\end{tabular}

Notes: MAT = mean annual temperature. MAP = mean annual precipitation. $\mathrm{PET}=$ potential evapotranspiration. $\mathrm{BD}=$ bulk density. $\mathrm{CEC}=$ cation exchange capacity.
Subsamples of soil from each horizon were sieved ( $2 \mathrm{~mm}$ [0.079 in] sieve size) and picked free of remaining recognizable plant and root fragments under $20 \times$ magnification (i.e., identifiable plant material). Soil samples were delimed using dilute phosphoric acid (Follett et al. 1997; Follett and Pruessner $2001)$, oven dried $\left(55^{\circ} \mathrm{C}\left[131^{\circ} \mathrm{F}\right]\right)$, and analyzed for total $\mathrm{N}$, primarily in the form of SON, and SOC using a Carlo Erba C/N analyzer (Haake Buchler Instruments, Saddle Brook, New Jersey). In reporting SON, mineral $\mathrm{N}$ is recognized as being present with measured nitrate + ammonium being $\leq 1 \%$ of total $\mathrm{N}$ for native and CRP, and for cropped (or very sandy land use locations), $<5 \%$ of total N.The cation exchange capacity (CEC) was determined by cation extraction with 
Table 4

Pearson Correlation Coefficients ( $r$ ) and $p$-values for climate and soil properties for cropped, Conservation Reserve Program (CRP), and native land uses (combined o to $10 \mathrm{~cm}$ depth) across 14 US Great Plains sites.

\begin{tabular}{|c|c|c|c|c|c|c|c|c|c|c|c|c|c|c|c|}
\hline Variable & MAT & MAP & PET & MAP:PET & BD & Sand & Silt & Clay & $\begin{array}{l}\text { Silt + } \\
\text { clay }\end{array}$ & CEC & $\mathrm{CaCO}_{3}$ & $\% \mathrm{C}$ & $\% \mathbf{N}$ & $\begin{array}{l}\text { Kg C } \\
\mathrm{ha}^{-1}\end{array}$ & $\begin{array}{l}\mathrm{Kg} \mathrm{N} \\
\mathrm{ha}^{-1}\end{array}$ \\
\hline MAT & 1 & & & & & & & & & & & & & & \\
\hline $\begin{array}{l}r= \\
p=\end{array}$ & $\begin{array}{l}0.956 \\
<.0001\end{array}$ & $\begin{array}{l}0.484 \\
0.001\end{array}$ & 1 & & & & & & & & & & & & \\
\hline $\begin{array}{l}r= \\
p=\end{array}$ & $\begin{array}{l}0.503 \\
0.001\end{array}$ & $\begin{array}{l}0.209 \\
0.145\end{array}$ & $\begin{array}{l}0.500 \\
0.001\end{array}$ & $\begin{array}{r}-0.203 \\
0.194\end{array}$ & 1 & & & & & & & & & & \\
\hline $\begin{array}{l}r= \\
p=\end{array}$ & $\begin{array}{r}-0.027 \\
0.866\end{array}$ & $\begin{array}{r}-0.126 \\
0.425\end{array}$ & $\begin{array}{r}-0.012 \\
0.938\end{array}$ & $\begin{array}{r}-0.080 \\
0.615\end{array}$ & $\begin{array}{l}0.494 \\
0.001\end{array}$ & 1 & & & & & & & & & \\
\hline $\begin{array}{l}r= \\
p=\end{array}$ & $\begin{array}{l}0.094 \\
0.553\end{array}$ & $\begin{array}{l}0.221 \\
0.160\end{array}$ & $\begin{array}{l}0.058 \\
0.718\end{array}$ & $\begin{array}{l}0.127 \\
0.423\end{array}$ & $\begin{array}{r}-0.481 \\
0.001\end{array}$ & $\begin{array}{l}-0.980 \\
<.0001\end{array}$ & 1 & & & & & & & & \\
\hline $\begin{array}{l}r= \\
p=\end{array}$ & $\begin{array}{r}-0.541 \\
0.000\end{array}$ & $\begin{array}{r}-0.098 \\
0.537\end{array}$ & $\begin{array}{r}-0.472 \\
0.002\end{array}$ & $\begin{array}{l}0.368 \\
0.016\end{array}$ & $\begin{array}{l}-0.685 \\
<.0001\end{array}$ & $\begin{array}{r}-0.635 \\
<.0001\end{array}$ & $\begin{array}{l}0.541 \\
0.000\end{array}$ & $\begin{array}{l}0.749 \\
<.0001\end{array}$ & $\begin{array}{l}0.635 \\
<.0001\end{array}$ & 1 & & & & & \\
\hline $\begin{array}{l}r= \\
p=\end{array}$ & $\begin{array}{r}-0.354 \\
0.021\end{array}$ & $\begin{array}{r}-0.286 \\
0.066\end{array}$ & $\begin{array}{r}-0.348 \\
0.024\end{array}$ & $\begin{array}{l}0.002 \\
0.993\end{array}$ & $\begin{array}{r}-0.057 \\
0.719\end{array}$ & $\begin{array}{l}0.048 \\
0.764\end{array}$ & $\begin{array}{r}-0.058 \\
0.715\end{array}$ & $\begin{array}{r}-0.017 \\
0.916\end{array}$ & $\begin{array}{r}-0.048 \\
0.764\end{array}$ & $\begin{array}{l}0.017 \\
0.915\end{array}$ & 1 & & & & \\
\hline $\begin{array}{l}r= \\
p=\end{array}$ & $\begin{array}{l}-0.607 \\
<.0001\end{array}$ & $\begin{array}{r}-0.145 \\
0.359\end{array}$ & $\begin{array}{l}-0.585 \\
<.0001\end{array}$ & $\begin{array}{l}0.401 \\
0.009\end{array}$ & $\begin{array}{l}-0.793 \\
<.0001\end{array}$ & $\begin{array}{r}-0.278 \\
0.074\end{array}$ & $\begin{array}{l}0.223 \\
0.138\end{array}$ & $\begin{array}{l}0.338 \\
0.029\end{array}$ & $\begin{array}{l}0.278 \\
0.074\end{array}$ & $\begin{array}{l}0.778 \\
<.0001\end{array}$ & $\begin{array}{l}0.096 \\
0.544\end{array}$ & 1 & & & \\
\hline $\begin{array}{l}r= \\
p=\end{array}$ & $\begin{array}{r}-0.625 \\
<.0001\end{array}$ & $\begin{array}{r}-0.117 \\
0.459\end{array}$ & $\begin{array}{l}-0.582 \\
<.0001\end{array}$ & $\begin{array}{l}0.435 \\
0.004\end{array}$ & $\begin{array}{c}-0.788 \\
<.0001\end{array}$ & $\begin{array}{r}-0.366 \\
0.017\end{array}$ & $\begin{array}{l}0.319 \\
0.039\end{array}$ & $\begin{array}{l}0.414 \\
0.006\end{array}$ & $\begin{array}{l}0.366 \\
0.017\end{array}$ & $\begin{array}{l}0.823 \\
<.0001\end{array}$ & $\begin{array}{l}0.181 \\
0.252\end{array}$ & $\begin{array}{l}0.969 \\
<.0001\end{array}$ & 1 & & \\
\hline $\begin{aligned} \mathrm{KgC} \mathrm{ha}^{-1} r & = \\
p & =\end{aligned}$ & $\begin{array}{r}-0.663 \\
<.0001\end{array}$ & $\begin{array}{r}-0.093 \\
0.560\end{array}$ & $\begin{array}{l}-0.624 \\
<.0001\end{array}$ & $\begin{array}{l}0.508 \\
0.001\end{array}$ & $\begin{array}{l}-0.668 \\
<.0001\end{array}$ & $\begin{array}{r}-0.284 \\
0.069\end{array}$ & $\begin{array}{l}0.236 \\
0.133\end{array}$ & $\begin{array}{l}0.348 \\
0.024\end{array}$ & $\begin{array}{l}0.284 \\
0.069\end{array}$ & $\begin{array}{l}0.793 \\
<.0001\end{array}$ & $\begin{array}{l}0.121 \\
0.447\end{array}$ & $\begin{array}{l}0.939 \\
<.0001\end{array}$ & $\begin{array}{l}0.947 \\
<.0001\end{array}$ & 1 & \\
\hline
\end{tabular}

Notes: $\mathrm{MAT}=$ mean annual temperature. MAP $=$ mean annual precipitation. $\mathrm{PET}=$ potential evapotranspiration. $\mathrm{BD}=$ bulk density. $\mathrm{CEC}=\mathrm{cation}$ exchange capacity. $\mathrm{CaCO}_{3}=$ calcium carbonate. $\mathrm{C}=$ carbon. $\mathrm{N}=$ nitrogen. Bold values represent interactions that were considered for further statistical analyses.

ammonium acetate, Soil Survey Laboratory method 4B4b1 (NRCS 2004). Particle-size distribution analysis (percentage sand, percentage silt, and percentage clay) was assessed using Soil Survey Laboratory method 3A1a (NRCS 2004).

Statistical Analyses. To determine the most appropriate variables for the ANCOVA model, we ran a Pearson Correlation analysis with the data from the three land uses (native, CRP, and cropped) from 14 sites for the 0 to $10 \mathrm{~cm}$ (0 to 3.9 in) depth (table 4). Fixed main treatment effects (native, CRP, or cropped) and covariates MAT, MAP:PET, BD, and percentage clay were evaluated using an ANCOVA by depth using SAS (Tulsa) PROC MIXED (SAS 2002 to 2008). In this design, differences between sites are blocked to more accurately assess land use differences (land use within site). Differences between treatment means were calculated as the least square means (LSMEANS). Only a small number of covariates-MAT, the ratio of MAP:PET, $\mathrm{BD}$, and percentage clay-were included in the final ANCOVA model for parsimony and to minimize possible confounding effects. For example, though highly significant, CEC was not included as it was highly correlated with the other soil properties used in the model. Differences with a $p$-value of less than 0.10 were considered significant.

Next, we developed separate predictive equations for individual climate and soil variables (fixed effects of MAT, MAP:PET and clay) using an ANCOVA model (PROC MIXED) with covariates of land use and their interaction. This analysis resulted in predictive equations for SOC and SON as a function of either MAT, MAP:PET, or clay. These predictive equations are straightforward, are based on a single variable, and assume other variables remain constant, but they do allow the general relationships between climate and soil properties to be predicted.

Evaluation of Climate and Soil Factors. Consideration of potential climate change effects on SOC and SON in the US Great Plains requires that soil $\mathrm{C}$ and $\mathrm{N}$ stocks are closely tied to various soil factors. To evaluate importance of climate across this broad region, it is appropriate to frame the discussion around the factors of soil formation that were identified by Jenny (1941), and that can be expressed in equation 1 :

$s=f(c l, o, r, p, t)$,

where $s$ is a dependent soil property that is a function of independent variables that define the soil system, i.e., $c l=$ climate, $o=$ organisms, $r=$ topography, $p=$ parent material, and $t=$ time. Because climate is so complex that no single numerical value can be assigned to a 
given climate, independent subfactors of climate, such as temperature $(T)$ and moisture $(m)$, can be expressed in separate equations:

$s=f(T) m, o, r, p, t$

$s=f(m) T, o, r, p, t$.

\section{Results and Discussion}

Percentage Soil Organic Carbon and Soil Organic Nitrogen. The percentage of SOC and percentage of SON were significantly affected by land use in the 0 to $5 \mathrm{~cm}(0$ to 2 in) $(p<0.05)$ and 0 to $10 \mathrm{~cm}(0$ to 3.9 in) $(p<0.10)$ depths. Least square means and their differences are shown in tables $5 b$ and $6 \mathrm{~b}$; both decreased significantly in the order of native $>\mathrm{CRP}>$ cropped in the 0 to 5 $\mathrm{cm}$ and 0 to $10 \mathrm{~cm}$ depths. The MAT was a significant covariate to land use for percentage SOC (table $5 \mathrm{a}$ ) in the 0 to $5 \mathrm{~cm}, 5$ to $10 \mathrm{~cm}$ (2 to $3.9 \mathrm{in}$ ), and 0 to $10 \mathrm{~cm}(p<0.10)$ and 10 to $30 \mathrm{~cm}$ (3.9 to $11.8 \mathrm{in})(p<0.05)$ depths, while MAP:PET was a significant covariate to land use for percentage SOC in the 5 to $10 \mathrm{~cm}$ and 0 to $10 \mathrm{~cm}(p<0.10)$ depths. The $\mathrm{BD}$ - as a covariate to land use-was significant for percentage SOC at all four depths $(p$ $<0.05$ to $p<0.001$ ), with the highest significance for 5 to $10 \mathrm{~cm}$ and 0 to $10 \mathrm{~cm}$ depths (table 5a). The percentage clay effect was not significant for percentage SOC at any depth. No significant interactions among the climate variables or soil descriptors were observed.

Land use was significant $(p<0.01)$ for percentage $\mathrm{SON}$ in the 0 to $5 \mathrm{~cm}(0$ to 2 in) and 0 to $10 \mathrm{~cm}$ (0 to 3.9 in) depths (table 6a). The MAT was a significant covariate to land use for percentage SON at $p<$ 0.05 for the 0 to $5 \mathrm{~cm}, 5$ to $10 \mathrm{~cm}$ (2 to 3.9 in), 0 to 10 , and 10 to $30 \mathrm{~cm} \mathrm{(3.9} \mathrm{to} 11.8$ in) depths (table 6a). MAP:PET was a significant covariate to land use for percentage SON at $p<0.1$ for the 0 to $5 \mathrm{~cm}$ and 10 to $30 \mathrm{~cm}$ depths, but significant at $p<0.05$ for the 5 to $10 \mathrm{~cm}$ and 0 to $10 \mathrm{~cm}$ depths. The soil $\mathrm{BD}$ was a significant covariate to land use for percentage $\mathrm{SOC}$ at the 0 to $5 \mathrm{~cm}$ $(p<0.05), 5$ to $10 \mathrm{~cm}(p<0.001), 0$ to 10 $\mathrm{cm}(p<0.01)$, and 10 to $30 \mathrm{~cm}(p<0.1)$ depths. For the percentage SON (table 6a), percentage clay was significant covariate to land use for the 0 to $5 \mathrm{~cm}(p<0.05)$ and 0 to $10 \mathrm{~cm}(p<0.10)$ depths. The climate and soil factors used had greater statistical significance for percentage SON than for percentage SOC (tables $5 \mathrm{~b}$ and $6 \mathrm{~b}$ ).

\section{Table 5}

Effects of three land uses (cropped, Conservation Reserve Program [CRP], and native) on (a and b) percentage of soil organic carbon (\% SOC) and (c and d) least square mean $\mathrm{kg} \mathrm{SOC} \mathrm{ha-}^{-1}$ for four depth increments from an analyses of covariance with covariates mean annual temperature (MAT), mean annual precipitation to potential evapotranspiration (MAP:PET), clod bulk density (BD) for \% SOC, and clay.

\begin{tabular}{llllll}
\hline Effect & $\mathbf{n}$ & $\begin{array}{l}\mathbf{0} \text { to } \mathbf{5} \mathbf{~ c m} \\
\boldsymbol{p} \text {-value }\end{array}$ & $\begin{array}{l}\mathbf{5} \text { to } \mathbf{1 0} \mathbf{~ c m} \\
\boldsymbol{p} \text {-value }\end{array}$ & $\begin{array}{l}\mathbf{0} \text { to } \mathbf{1 0} \mathbf{~ c m} \\
\boldsymbol{p} \text {-value }\end{array}$ & $\begin{array}{l}\mathbf{1 0} \text { to } \mathbf{3 0} \mathbf{~ c m} \\
\boldsymbol{p} \text {-value }\end{array}$ \\
\hline Land use & 2 & $0.014 * *$ & 0.671 & $0.077^{*}$ & 0.628 \\
MAT & 1 & $0.053^{*}$ & $0.051 *$ & $0.051^{*}$ & $0.047 * *$ \\
MAP/PET & 1 & 0.129 & $0.096 *$ & $0.096 *$ & 0.110 \\
BD & 1 & $0.013 * *$ & $0.000 * * * *$ & $0.001 * * * *$ & $0.029 * *$ \\
Clay & 1 & 0.125 & 0.985 & 0.370 & 0.900 \\
\hline
\end{tabular}

(b)

\begin{tabular}{llll} 
Depth $\mathbf{( c m )}$ & Cropped & CRP & Native \\
\hline 0 to 5 & $1.734 a$ & $2.291 \mathrm{~b}$ & $3.085 \mathrm{c}$ \\
5 to 10 & $1.571 \mathrm{a}$ & $1.703 \mathrm{a}$ & $1.767 \mathrm{a}$ \\
0 to 10 & $1.669 \mathrm{a}$ & $1.994 \mathrm{ab}$ & $2.413 \mathrm{~b}$ \\
10 to 30 & $1.007 \mathrm{a}$ & $1.096 \mathrm{a}$ & $1.127 \mathrm{a}$ \\
\hline
\end{tabular}

(c)

\begin{tabular}{ccllll} 
Effect & $\mathbf{n}$ & $\begin{array}{l}\mathbf{0} \text { to } \mathbf{5} \mathbf{~ c m} \\
\boldsymbol{p} \text {-value }\end{array}$ & $\begin{array}{l}\mathbf{5} \text { to } \mathbf{1 0} \mathbf{~ c m} \\
\boldsymbol{p} \text {-value }\end{array}$ & $\begin{array}{l}\mathbf{0} \text { to } \mathbf{1 0} \mathbf{~ c m} \\
\boldsymbol{p} \text {-value }\end{array}$ & $\begin{array}{l}\mathbf{1 0} \text { to } \mathbf{3 0} \mathbf{~ c m} \\
\boldsymbol{p} \text {-value }\end{array}$ \\
\hline Land use & 2 & $0.000 * * * *$ & $0.057 *$ & $0.001 * * * *$ & 0.478 \\
MAT & 1 & $0.000 * * * *$ & $0.002 * * *$ & $0.000 * * * *$ & $0.021 * * *$ \\
MAP/PET & 1 & $0.009 * * *$ & $0.013 * *$ & $0.001 * * * *$ & 0.120 \\
Clay & 1 & $0.004 * * *$ & $0.028 * *$ & $0.002 * * *$ & 0.237 \\
\hline
\end{tabular}

(d)

\begin{tabular}{lrll} 
Depth $\mathbf{( c m )}$ & Cropped & CRP & Native \\
\hline 0 to 5 & $9,019 a$ & $12,947 b$ & $16,905 \mathrm{c}$ \\
5 to 10 & $9,418 \mathrm{a}$ & $10,074 \mathrm{ab}$ & $12,646 \mathrm{~b}$ \\
0 to 10 & $18,438 \mathrm{a}$ & $23,013 \mathrm{a}$ & $29,557 \mathrm{~b}$ \\
10 to 30 & $26,776 \mathrm{a}$ & $29,459 \mathrm{a}$ & $30,843 \mathrm{a}$ \\
\hline
\end{tabular}

Note: Different letters in tables $b$ and $d$ indicate land use effects that were significantly different within each depth increments $(p=0.05)$.

$* p<.1 * * p<.05 * * * p<.01 * * * * p<.001$

Soil Organic Carbon and Nitrogen (kilograms per hectare). The $\mathrm{kg} \mathrm{ha}^{-1}$ of SOC and SON were significantly affected by land use at the 0 to $5 \mathrm{~cm}$ ( 0 to 2 in) and 0 to $10 \mathrm{~cm}(0$ to 3.9 in) depths $(p<0.001, p<0.01)$, while for $\mathrm{kg} \mathrm{SOC} \mathrm{ha-1}$, land use was also significant $(p<0.1)$ at the 5 to $10 \mathrm{~cm}$ (2 to 3.9 in) depth (tables $5 \mathrm{c}$ and $6 \mathrm{c}$ ). The MAT was a significant covariate to land use for both $\mathrm{kg} \mathrm{ha}^{-1}$ SOC and $\mathrm{kg} \mathrm{ha}^{-1} \mathrm{SON}$ at all depth increments. The MAP:PET and percentage clay were both significant covariates to land use for $\mathrm{kg} \mathrm{SOC} \mathrm{ha}{ }^{-1}$ in the top three depth increments but not for the 10 to $30 \mathrm{~cm}$ (3.9 to $11.8 \mathrm{in}$ ) depth (table $5 c)$. The MAP:PET was a significant covariate to land use for $\mathrm{kg} \mathrm{SON} \mathrm{ha}{ }^{-1}$ in all four depths, while percentage clay was significant as a covariate to land use for $\mathrm{kg} \mathrm{SON} \mathrm{ha}^{-1}$ in only the top three depth increments (table 6c).
Least square means of $\mathrm{kg} \mathrm{SOC} \mathrm{ha}{ }^{-1}$ decreased in the top three depth increments in the order of native $>$ CRP $>$ cropped (table $5 d$ ). For the $\mathrm{kg} \mathrm{SON} \mathrm{ha}{ }^{-1}$, least square means decreased in the order of native $>$ CRP $>$ cropped only in the 0 to $5 \mathrm{~cm}$ ( 0 to $2 \mathrm{in})$ and in the 0 to 10 $\mathrm{cm}$ (0 to $3.9 \mathrm{in}$ ) depth increments (table $6 \mathrm{~d}$ ).

Climate and Soil Property Effects on Soil Organic Carbon and Soil Organic Nitrogen Stocks. To further determine individual effects of climatic and soil properties on SOC and SON stocks, we analyzed MAT, MAP:PET, and percentage clay with $\mathrm{kg}$ SOC ha ${ }^{-1}$ and $\mathrm{kg} \mathrm{SON} \mathrm{ha}{ }^{-1}$ for the 0 to 10 $\mathrm{cm}$ (0 to $3.9 \mathrm{in})$ depth increment. This depth showed the most significance in covariates, is the youngest soil layer (Follett et al. 2004), and likely best retains the signal of the recent climate (Leavitt et al. 2007). 


\section{Table 6}

Effects of three land uses (cropped, Conservation Reserve Program [CRP], and native) on $(a$ and $b)$ percentage of soil organic nitrogen (\% SON) and ( $c$ and d) least square mean kg SON $\mathrm{ha}^{-1}$ for four depth increments from an analyses of covariance with covariates mean annual temperature (MAT), mean annual precipitation to potential evapotranspiration (MAP:PET), clod bulk density (BD) for \% SON, and clay.

\begin{tabular}{llllll}
\hline Effect & $\mathbf{n}$ & $\begin{array}{l}\mathbf{0} \text { to } \mathbf{5} \mathbf{~ c m} \\
\boldsymbol{p} \text {-value }\end{array}$ & $\begin{array}{l}\mathbf{5} \text { to } \mathbf{1 0} \mathbf{~ c m} \\
\boldsymbol{p} \text {-value }\end{array}$ & $\begin{array}{l}\mathbf{0} \text { to } \mathbf{1 0} \mathbf{~ c m} \\
\boldsymbol{p} \text {-value }\end{array}$ & $\begin{array}{l}\mathbf{1 0} \text { to } \mathbf{3 0} \mathbf{~ c m} \\
\boldsymbol{p} \text {-value }\end{array}$ \\
\hline Land use & 2 & $0.004 * * *$ & 0.821 & $0.047 * * *$ & 0.933 \\
MAT & 1 & $0.022 * *$ & $0.037 * * *$ & $0.023 * * *$ & $0.026 * * *$ \\
MAP:PET & 1 & $0.059 *$ & $0.039 * * *$ & $0.034 * * *$ & $0.055 *$ \\
BD & 1 & $0.026 * *$ & $0.000 * * * *$ & $0.003 * * *$ & $0.086 *$ \\
Clay & 1 & $0.020 * *$ & 0.655 & $0.094 *$ & 0.630 \\
\hline
\end{tabular}

(b)

\begin{tabular}{llll} 
Depth $\mathbf{( c m )}$ & Cropped & CRP & Native \\
\hline 0 to 5 & $0.195 a$ & $0.242 a$ & $0.324 b$ \\
5 to 10 & $0.182 a$ & $0.189 a$ & $0.196 a$ \\
0 to 10 & $0.189 a$ & $0.215 a b$ & $0.260 b$ \\
10 to 30 & $0.130 a$ & $0.136 a$ & $0.133 a$ \\
\hline
\end{tabular}

(c)

\begin{tabular}{llllll} 
(c) & & $\begin{array}{l}\mathbf{0} \text { to } \mathbf{5} \mathbf{~ c m} \\
\boldsymbol{p} \text {-value }\end{array}$ & $\begin{array}{l}\mathbf{5} \text { to } \mathbf{1 0} \mathbf{~ c m} \\
\boldsymbol{p} \text {-value }\end{array}$ & $\begin{array}{l}\mathbf{0} \text { to } \mathbf{1 0} \mathbf{~ c m} \\
\boldsymbol{p} \text {-value }\end{array}$ & $\begin{array}{l}\mathbf{1 0} \text { to } \mathbf{3 0} \mathbf{~ c m} \\
\boldsymbol{p} \text {-value }\end{array}$ \\
\hline Land use & 2 & $0.001 * * * *$ & 0.3084 & $0.010 * * *$ & 0.953 \\
MAT & 1 & $0.001 * * * *$ & $0.000 * * * *$ & $0.000 * * * *$ & $0.007 * * *$ \\
MAP:PET & 1 & $0.008 * * *$ & $0.000 * * * *$ & $0.000 * * * *$ & $0.042 * * *$ \\
Clay & 1 & $0.001 * * * *$ & $0.000 * * * *$ & $0.000 * * * *$ & 0.141 \\
\hline
\end{tabular}

(d)

\begin{tabular}{llll} 
Depth $(\mathbf{c m})$ & Cropped & CRP & Native \\
\hline 0 to 5 & $1,063 a$ & $1,398 \mathrm{ab}$ & $1,733 \mathrm{~b}$ \\
5 to 10 & $1,149 \mathrm{a}$ & $1,151 \mathrm{a}$ & $1,340 \mathrm{a}$ \\
0 to 10 & $2,212 \mathrm{a}$ & $2,549 \mathrm{ab}$ & $3,074 \mathrm{~b}$ \\
10 to 30 & $3,524 \mathrm{a}$ & $3,652 \mathrm{a}$ & $3,571 \mathrm{a}$ \\
\hline
\end{tabular}

Note: Different letters in tables $b$ and $d$ indicates land use effects that were significantly different within each depth increments $(p=0.05)$.

$* p<.1 * * p<.05 * * * p<.01 * * * * p<.001$
Mean Annual Temperature (MAT). Both SOC and SON decreased as MAT increased (table 7). The SOC and SON decreases were 1,896 and $178 \mathrm{~kg} \mathrm{ha}^{-1}$ per $1^{\circ} \mathrm{C}(1,691$ and $159 \mathrm{lb} \mathrm{ac}^{-1}$ per $\left.1.8^{\circ} \mathrm{F}\right)$ temperature increase in MAT, respectively. The relationship was the same regardless of land use (i.e., no significant interaction), so a general equation was able to predict SOC decrease across all land uses evaluated in this study. The regression equation in metric units for $\mathrm{kg}$ SOC ha ${ }^{-1}$ as a function of MAT was SOC $\left(\mathrm{kg} \mathrm{ha}^{-1}\right)=$ $-1,896 \pm 339 \times{ }^{\circ} \mathrm{C}+41,424 \pm 3,511$ (the same equation expressed in English units is SOC $\left[1 \mathrm{~b} \mathrm{ac}{ }^{-1}\right]=-940 \pm 168 \times{ }^{\circ} \mathrm{F}+67,090$ $\pm 8,319)$. The standard error for the slope and intercept result from the scatter of the data within the different land uses (figure 3a). Similarly, the regression equation in metric units for $\mathrm{kg} \mathrm{SON} \mathrm{ha}{ }^{-1}$ as a function of MAT was SON $\left(\mathrm{kg} \mathrm{ha}^{-1}\right)=-178 \pm 34 \times{ }^{\circ} \mathrm{C}+$ $4,279 \pm 358$ (the same equation expressed in English units is SON $\left[\mathrm{lb} \mathrm{ac}^{-1}\right]=-88 \pm 17 \times$ ${ }^{\circ} \mathrm{F}+6,647 \pm 849$ ) (figure 4a).

Ratio of Mean Annual Precipitation to Potential Evapotranspiration (MAP:PET). Both SOC and SON were significantly $(p<$ 0.05 ) positively related to MAP:PET (table 7). There was no significant interaction with land use, so a single equation will predict the amount of SOC increase across all land uses assuming all other parameters remain the same. The regression equation in metric units for $\mathrm{kg} \mathrm{SOC} \mathrm{ha-1}$ as a function of MAP:MAT was SOC $\left(\mathrm{kg} \mathrm{ha}^{-1}\right)=28,310 \pm 7,594 \mathrm{~kg}$ $\mathrm{ha}^{-1} \times$ MAP:MAP $+850 \pm 8,515$ (the same equation expressed in English units is SOC $\left[\mathrm{lb} \mathrm{ac} \mathrm{ac}^{-1}\right]=25,280 \pm 6,781 \times$ MAP:MAT $+759 \pm 5,680$ ) (figure $3 \mathrm{~b}$ ). The regression

\section{Table 7}

Predictive equations for singular effects of mean annual temperature (MAT), MAT to potential evapotranspiration ratio (MAT:PET), and percentage clay on $\mathrm{kg}$ soil organic carbon (SOC) ha ${ }^{-1}$ and $\mathrm{kg}$ soil organic nitrogen (SON) ha- ${ }^{-1}$ stocks. The covariate land use and its interaction were included in the ANCOVA, but significant only with clay $(n=42)$.

\begin{tabular}{|c|c|c|c|c|c|}
\hline Variable & Land use & $\begin{array}{l}\text { kg SOC ha-1 } \\
\text { equation }\end{array}$ & $\operatorname{Pr}>\mathbf{F}$ & $\begin{array}{l}\text { kg SON ha-1 } \\
\text { equation }\end{array}$ & $\operatorname{Pr}>\mathrm{F}$ \\
\hline MAT & NS & $y=(-1,896 \pm 339) x+41,424 \pm 3,511$ & $>0.0001$ & $y=(-178 \pm 34) x+4,279 \pm 358$ & 0.002 \\
\hline Clay $\times$ land use & & & 0.004 & & 0.011 \\
\hline \multirow[t]{2}{*}{ Clay } & Native & $y=(+1,203 \pm 339) x+4,689 \pm 7,567$ & & $y=(+95 \pm 35) x+1,104 \pm 784$ & \\
\hline & CRP & $y=(+105 \pm 294) x+20,951 \pm 6,551$ & & $y=(-11 \pm 32) x+2,804 \pm 718$ & \\
\hline
\end{tabular}

Notes: NS = not significant. CRP $=$ Conservation Reserve Program. 


\section{Figure 3}

Soil organic carbon ( $\mathrm{kg} \mathrm{SOC} \mathrm{ha-1)} \mathrm{as} \mathrm{a} \mathrm{function} \mathrm{of} \mathrm{(a)} \mathrm{mean} \mathrm{annual} \mathrm{temperature} \mathrm{and} \mathrm{(b)} \mathrm{the} \mathrm{ratio}$ of mean annual precipitation to potential evapotranspiration for native, Conservation Reserve Program (CRP), and cropped sites across the US Great Plains.

(a)

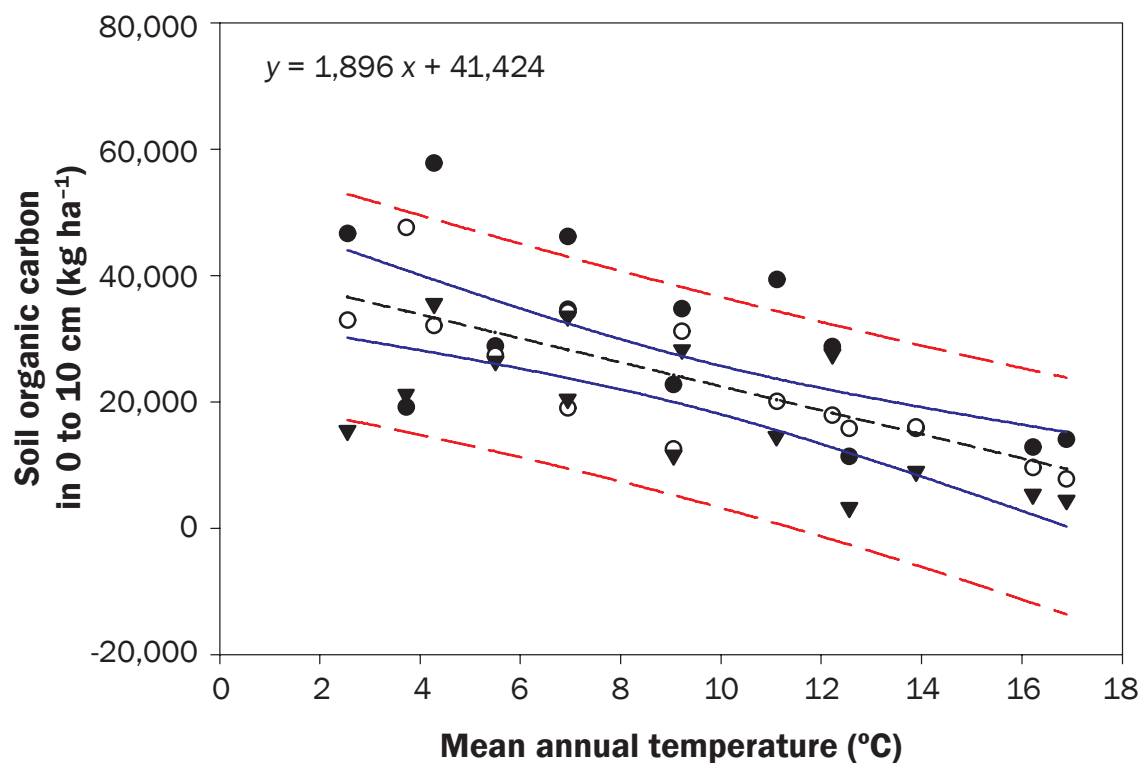

(b)

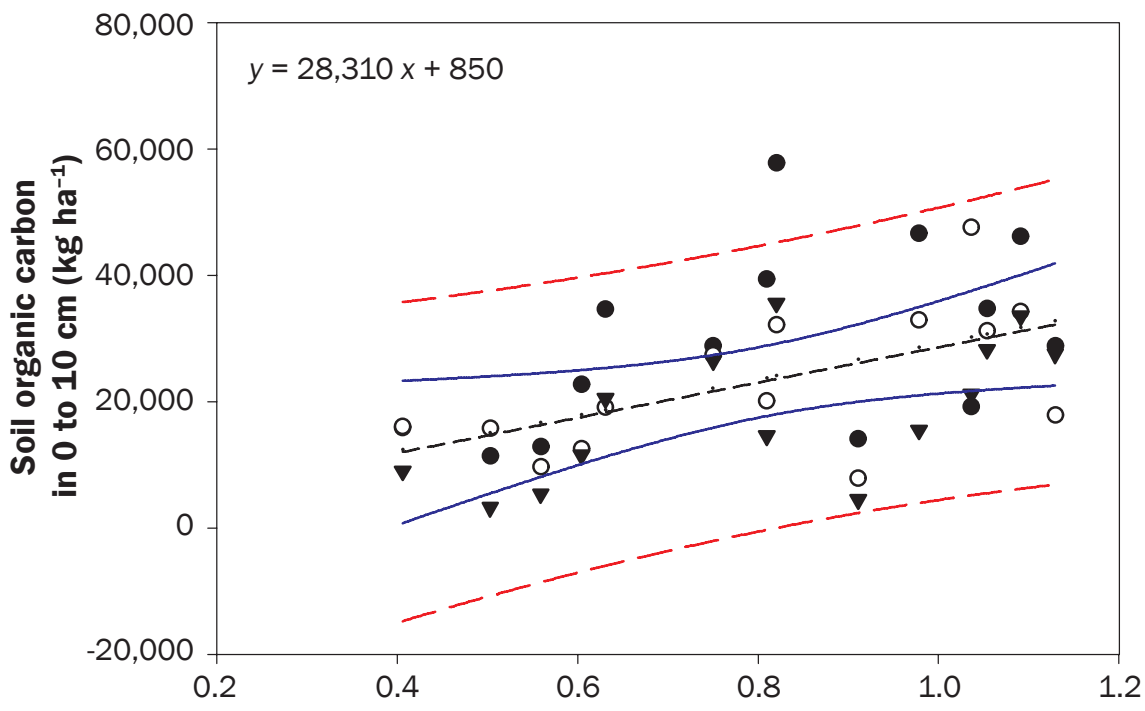

Mean annual preciptation: potential evapotranspiration

Legend

- $\mathrm{Kg} \mathrm{C} \mathrm{ha-1}$ native

O Kg C ha-1 CRP

$\nabla \mathrm{Kg} \mathrm{C} \mathrm{ha-1}$ crop

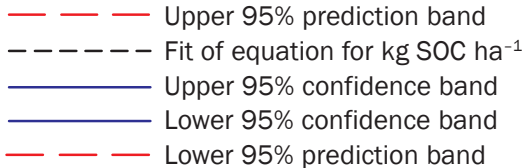

equation in metric units for $\mathrm{kg} \mathrm{SON} \mathrm{ha}^{-1}$ is SON $\left(\mathrm{kg} \mathrm{ha}^{-1}\right)=2,980 \pm 730 \times$ MAP:MAT $+210 \pm 611$ (the same equation expressed in metric units is SON $\left[\mathrm{lb} \mathrm{ac}^{-1}\right]=2,661 \pm$ $652 \times$ MAP:MAT + $188 \pm 546$ ) (figure 4b).

Percentage Clay. Unlike the climate variables, land use was a significant covariate with SOC and SON stocks across the range of climate, soil (table 1 and 3), and vegetation (table 2) that occurred for the sites sampled. Soil organic C stocks increased significantly with increasing percentage soil clay $(p<0.01)$ (table 7). Under native grassland, SOC and SON increased at the rates of $1,203 \mathrm{~kg} \mathrm{ha}^{-1}$ and $95 \mathrm{~kg}$ $\mathrm{ha}^{-1}\left(1,073\right.$ and $\left.85 \mathrm{lb} \mathrm{ac}^{-1}\right)$ per unit (\%) increase in clay, respectively (table 7). The respective rates of change in SOC and SON under cropland were +105 and $-11 \mathrm{~kg} \mathrm{ha}^{-1}$ (+94 and -10 $\mathrm{lb} \mathrm{ac}^{-1}$ ) and under CRP were 498 and $39 \mathrm{~kg}$ $\mathrm{ha}^{-1}$ (444 and $35 \mathrm{lb} \mathrm{ac}^{-1}$ ), respectively.

Discussion: Temperature. Our results confirm other studies that find a negative relationship between MAT and SOC stocks (Dijkstra and Morgan 2012; Homann et al. 2007; Jobbagy and Jackson 2000; Burke et al. 1989). Based upon geographic location and dominant vegetation, Homann et al. (2007) observed that SOC in the $20 \mathrm{~cm}$ (7.9 in) depth was negatively correlated to MAT for all seven ecological regions that make up the conterminous United States except in the Northwest temperate forest region. Temperature and SOC stocks were strongly negatively related in a database analysis including about 300 pedons representing cultivated soils and 500 pedons representing rangeland soils from the central US Great Plains (Burke et al. 1989). Burke et al. (1989) found MAT to be the best predictor in a full quadratic predictive model for SOC and SON within the top $20 \mathrm{~cm}$ (7.9 in). They observed SOC and SON to decrease with increasing MAT to about $17^{\circ} \mathrm{C}\left(62.6^{\circ} \mathrm{F}\right)$ where it then leveled off. However, their range of MAT did not extend into MATs that would provide definitive information about future projected temperature increases.

Decreases in SOC stocks with increasing temperature can be linked to increasing soil respiration and SOM decomposition (Conant et al. 2004; Del Grosso et al. 2005) and/or decreased primary productivity and, consequently, soil C input. Studies of the effect of increasing temperature on SOC find increased respiration, although the rate of increase (over 10 degrees or $\mathrm{Q}_{10}$ ) is not always consistent (Smith et al. 2008; Del 


\section{Figure 4}

Soil organic nitrogen ( $\mathrm{kg} \mathrm{SON} \mathrm{ha}^{-1}$ ) as a function of (a) mean annual temperature and (b) the ratio of mean annual precipitation to potential evapotranspiration for native, Conservation Reserve Program (CRP), and cropped sites across the US Great Plains.

(a)

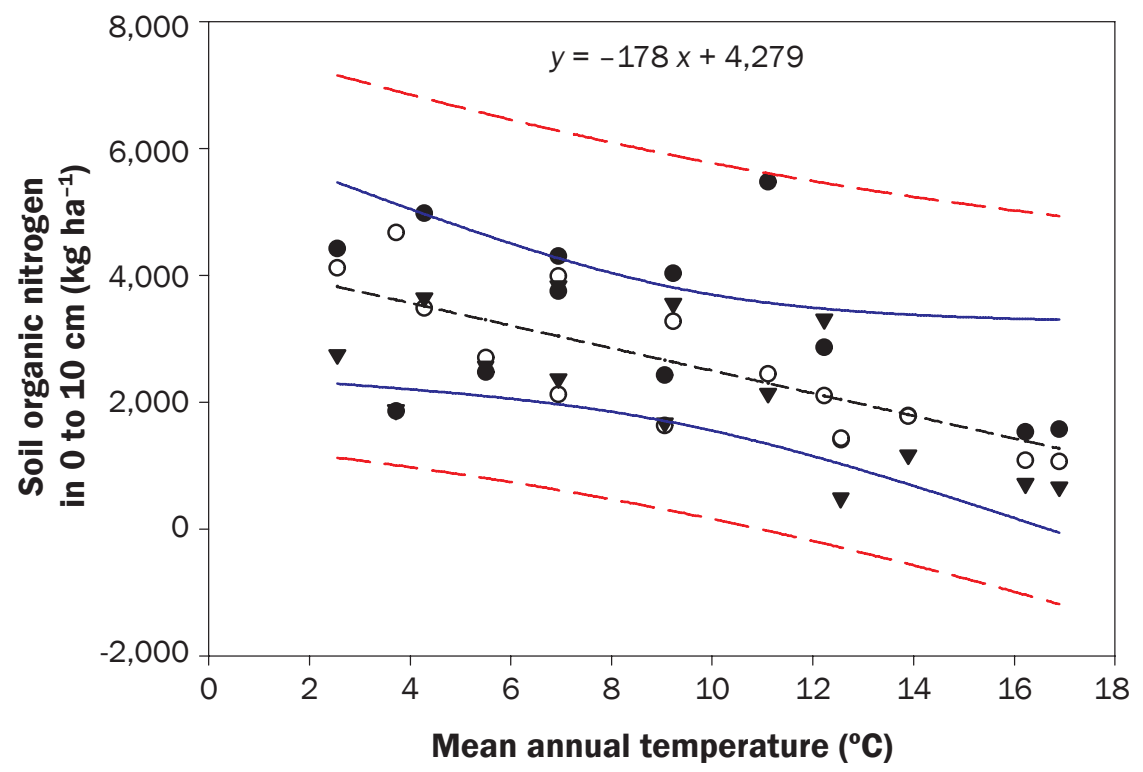

(b)

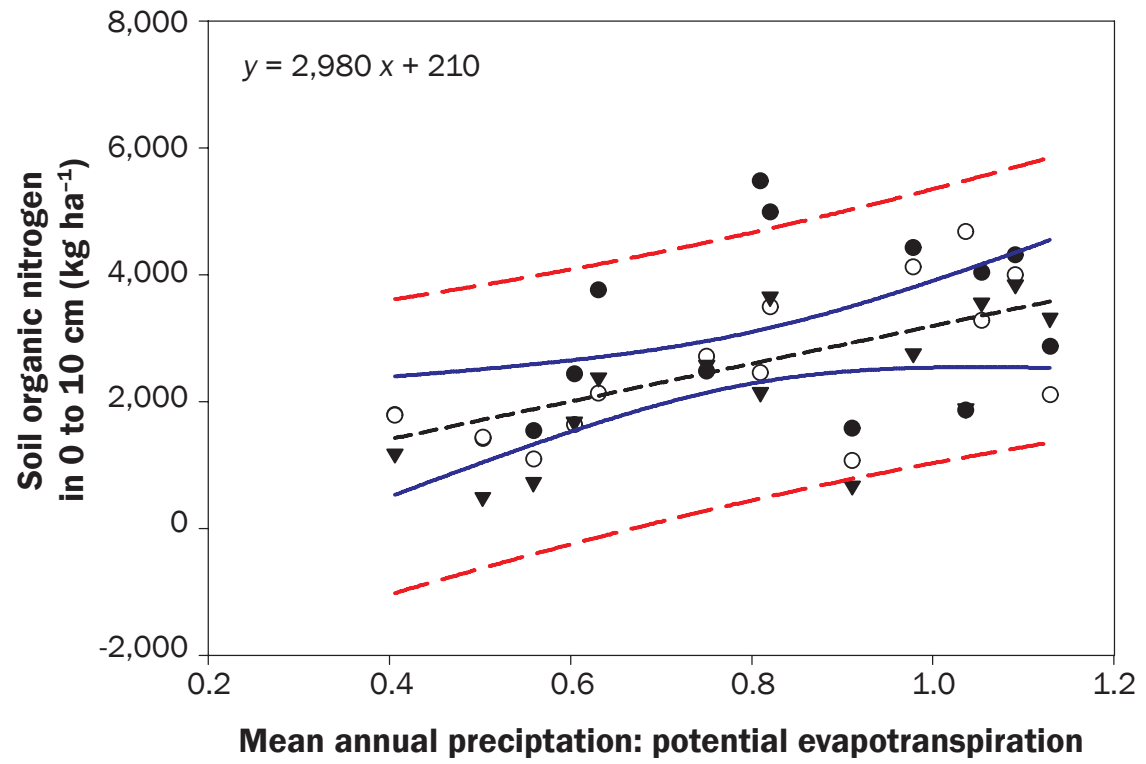

Legend

- $\mathrm{Kg} \mathrm{N}$ ha-1 native

O $\mathrm{Kg} \mathrm{N}_{\mathrm{Na}}{ }^{-1} \mathrm{CRP}$

$\boldsymbol{\nabla} \mathrm{Kg} \mathrm{N} \mathrm{ha}^{-1}$ crop

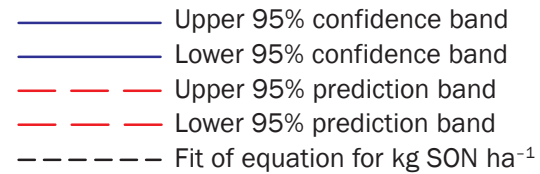

Grosso et al. 2005). In an analysis of $\mathrm{CO}_{2}$ emission data from agricultural systems (Michigan), forests (Wyoming, Massachusetts, and Germany), and grasslands (Colorado, Nebraska, and Kansas), $\mathrm{CO}_{2}$ efflux from soil was best fit by an arc-tangential relationship to temperature that indicated decreased respiration response to temperature above $20^{\circ} \mathrm{C}$ (68 $\left.{ }^{\circ} \mathrm{F}\right)$ (Del Grosso et al. 2005).

Discussion: Water. In this study, the MAP:PET ratio was significant, but MAP, as an individual factor, was not. However, other studies in grassland regions have found significant effects of MAP on SOC stocks. The model of Burke et al. (1989) showed an increase in SOC with increasing MAP to about $80 \mathrm{~cm}$ (31.5 in) per year. The ratio of MAP:PET is in essence an estimate of available water, so an increase in SOC with an increase this ratio agrees with studies that find an increase in SOC with increasing MAP. Researchers have hypothesized that precipitation effects on SOC stocks are mediated through changes in vegetation via primary productivity (i.e., forest to grassland) (Homann et al. 2007). In the Great Plains, primary productivity is strongly limited by moisture (Epstein et al. 1996).

In dryland systems, temperature and moisture interact to determine soil respiration (and consequently SOC loss). Del Grosso et al. (2005) included a water stress factor in their model of soil respiration, but found it only significant in dryland soils, indicating a significant interaction of temperature and moisture in water-limited systems. Conant et al. (2004) also reported that soil moisture can strongly influence soil respiration, particularly during dry or warm periods of the year. In a laboratory study, they found soil respiration to generally be directly related to temperature, but with respiration responses ameliorated by a decrease in soil moisture. Of course, the magnitude of SOC and SON loss will also be associated with the temperature sensitivity of labile versus recalcitrant SOM pools (Smith et al. 2008; Conant et al. 2011).

Discussion: Clay. The importance of soil texture on SOC stocks is well known, although not always evident. Other researchers have found that increased SOC and SON stocks are correlated with increased soil silt and clay content (Burke et al. 1989; Jabbagy and Jackson 2000). Land use was a significant covariate with climate in the predictive equations for $\mathrm{kg} \mathrm{SOC} \mathrm{ha}{ }^{-1}$ and $\mathrm{kg} \mathrm{SON} \mathrm{ha}{ }^{-1}$ (table 7). Land use was a significant covari- 
ate with clay content for the native soils and had a greater slope than the CRP or cropped land use. Interestingly, CRP had a smaller slope than did cropped land, possibly because of less uniformity in the manner that land owners selected the land they offered into the CRP program vs. the land they chose to continue cropping.

Future Scenarios. Climate change scenarios for the United States predict about a $2.2^{\circ} \mathrm{C}$ to $3.6^{\circ} \mathrm{C}\left(4^{\circ} \mathrm{F}\right.$ to $\left.6.5^{\circ} \mathrm{F}\right)$ increase in temperature across most of the United States over approximately the next 30 years (by 2040 to 2059) with summer temperature increases larger than in winter and greater increases in the southern and central Great Plains (USGCRP 2009). Precipitation intensity and variability will increase. Generally, northern areas are expected to receive more future precipitation during winter and spring because of warm, moist air from the south interacting with colder air from the north (USGCRP 2009). The analysis here used SOC and SON as an integrative measure of productivity and decomposition across existing gradients in temperature and precipitation. Using this data set, we asked, "Can future climate effects on SOC and SON be determined from existing patterns of SOC/ SON and 30-year climate data?"

The above analyses found that all else equal, across all land uses a warmer climate will result in a decrease in SOC and SON but that the decrease will be mediated by water availability (MAP:PET). Regression analyses indicate both the SOC (figures $3 \mathrm{a}$ and $4 \mathrm{a}$ ) and SON (table 7) may decrease across this region if long-term MAT increases, as might result from a warming climate. However these same analyses indicate that the effects of MAT on SOC and SON would be modified by the effect of the MAP:PET ratio (figures $3 \mathrm{~b}$ and $4 \mathrm{~b}$ ). Parton et al. (2012) report that observed patterns of rainfall within portions of the shortgrass prairie in the US Great Plains suggest a net loss of SOC may have occurred during the last 40 years, and should the trend toward more frequent but smaller precipitation events continue, continued losses of $\mathrm{C}$ from the system can be expected. To account for the influence of climate, Parton et al. (2012) further suggest that in drought years plant productivity cannot compensate for microbial decomposition.

Assuming a $1^{\circ} \mathrm{C}\left(1.8^{\circ} \mathrm{F}\right)$ increase in temperature across the Great Plains with a suitable time lag to allow for the SOC and
SON stocks to respond and also assuming the MAP:PET effect is net neutral, our analysis suggests a rate of decrease of about $1,900 \mathrm{~kg} \mathrm{SOC} \mathrm{ha}{ }^{-1}$ per $1^{\circ} \mathrm{C}\left(1,695 \mathrm{lb} \mathrm{ac}^{-1}\right.$ per $1.8^{\circ} \mathrm{F}$ ) increase of MAT (figure $3 \mathrm{a}$ ), which is equal to about $8 \%$ of the average total SOC (across the native, CRP, and cropped land uses) of 23,670 kg SOC ha-1 $(21,120 \mathrm{lb} \mathrm{SOC}$ $\mathrm{ac}^{-1}$ ) present in the top $10 \mathrm{~cm}$ (3.9 in) layer of soil (table $5 \mathrm{~b}$ ). Our assumption of a $1^{\circ} \mathrm{C}$ increase in temperature can allow this information to be scaled either up (or down) to relate to rates of temperature increases less than or as large as those forecasted by the USGCRP (2009). For example, Parton et al. (2012) indicated a dry-year decrease in SOC stock of $9.9 \mathrm{~g} \mathrm{~m}^{2}$ or $99 \mathrm{~kg} \mathrm{ha}^{-1}\left(88.4 \mathrm{lb} \mathrm{ac}^{-1}\right)$ that, when divided by the rate of decrease of $1,900 \mathrm{~kg} \mathrm{ha}^{-1}$ per $1^{\circ} \mathrm{C}$ from our data across the Great Plains, would indicate the average annual temperature increase for that one year to be $0.05^{\circ} \mathrm{C}\left(0.09^{\circ} \mathrm{F}\right)$, or if temperature were to increase at that annual rate for another 20 years, the equivalent MAT would be $1^{\circ} \mathrm{C}$ higher. However, this amount does not address effects of soil respiration, microbial sensitivity to temperature, relative influence of MAP to PET, or effects of rising $\mathrm{CO}_{2}$ over the next 30 years. Perhaps most worrisome is that if PET increases in parts of the US Great Plains with increased temperatures, then possible decreases of SOC and SON could be greater than the above predictions based on only increases in MAT. However, if MAP increases in parts of the US Great Plains with no change or a decrease in PET, then the effect of increased MAT could be partly offset in proportion to the MAP:PET ratio.

The data from this study apply primarily to the US Great Plains. The area of US Great Plains (extending about $800 \mathrm{~km}$ [497 mi] east to west and $3,200 \mathrm{~km}$ [1,987 mi] north to south) is about 256 Mha (632 million ac) (Wishart 2004). Based upon the $\mathrm{kg} \mathrm{ha}^{-1}$ (lb $\mathrm{ac}^{-1}$ ) of SOC and SON within the top $10 \mathrm{~cm}$ (3.9 in) of soil (tables $5 \mathrm{~d}$ and $6 \mathrm{~d}$ ), the stock averages are about 23,670 and $2,610 \mathrm{~kg} \mathrm{ha}^{-1}$ $\left(21,120\right.$ and 2,329 $\left.\mathrm{lb} \mathrm{ac}^{-1}\right)$ of SOC and SON, respectively. Consequently, across $256 \mathrm{Mha}$, estimates of the stocks are $\sim 6.059 \mathrm{Pg}$ SOC (6.68 billion $\mathrm{tn}$ ) and $\sim 0.668 \mathrm{Pg} \mathrm{SON}(0.683$ billion tn), respectively. Our estimates of the rates of loss are about $1,900 \mathrm{~kg}$ SOC and 180 $\mathrm{kg} \mathrm{SON} \mathrm{ha} \mathrm{h}^{-1}$ per $1^{\circ} \mathrm{C}\left(1,695\right.$ and $160 \mathrm{lb} \mathrm{ac}^{-1}$ per $1.8^{\circ} \mathrm{F}$ ) increase of MAT (figures $3 \mathrm{a}$ and $4 a$ ), which is equal to about $8 \%$ and $7 \%$ of the average total SOC and SON, respectively, pres- ent in the top $10 \mathrm{~cm}$ (3.9 in) layer of soil across native, CRP, and cropped (table $5 \mathrm{~d}$ and $6 \mathrm{~d}$ ).

Important gaps exist, but based upon equations and changes with increases in MAT (table 7 and figures 3 and 4) and estimates of $\mathrm{kg} \mathrm{ha}^{-1}$ of SOC and SON per $10 \mathrm{~cm}$ (3.9 in) depth, a $1^{\circ} \mathrm{C}\left(1.8^{\circ} \mathrm{F}\right)$ increase in MAT could decrease the SOC across the 13.6 Mha (33.7 million acres) of land in CRP by an estimated $320 \mathrm{Tg}$ SOC (352 million tn SOC) and $35 \mathrm{Tg}$ SON (38 million th of SON).

For an additional perspective, if a $3^{\circ} \mathrm{C}$ $\left(5.4^{\circ} \mathrm{F}\right)$ temperature increase were assumed to occur across the US Great Plains rather than $1^{\circ} \mathrm{C}\left(1.8^{\circ} \mathrm{F}\right)$, and if at a linear rate of increase during the next 30 years, the annual loss could be three times that discussed above, the amounts would be $190 \mathrm{~kg}$ SOC ha $\mathrm{h}^{-1} \mathrm{y}^{-1}$ and $18 \mathrm{~kg} \mathrm{SON} \mathrm{ha}^{-1} \mathrm{y}^{-1}$ across the $256 \mathrm{Mha}$ of land in the US Great Plains, i.e., 48.6 Tg (49.7 million tn) SOC $\mathrm{y}^{-1}$ or $178 \mathrm{Tg}$ (196.4 million tn) $\mathrm{CO}_{2} \mathrm{e}^{-1}$ and $4.61 \mathrm{Tg}$ (5.08 million tn) $\mathrm{SON} \mathrm{y}{ }^{-1}$. The US Environmental Protection Agency (2010) reports that greenhouse gas emissions in 2008 for the US agricultural sector was $504 \mathrm{Tg}$ (555 million tn) $\mathrm{CO}_{2} \mathrm{e} \mathrm{y}^{-1}$. Thus, following a $3^{\circ} \mathrm{C}$ temperature increase, the $\mathrm{CO}_{2} \mathrm{e}^{-1}$ resulting from annual losses of SOC for the US Great Plains would potentially account for about $39 \%$ of the 2008 US agricultural greenhouse gas emissions.

If MAT increases the rate of SOC loss and the $\mathrm{CO}_{2}$ release into the atmosphere is equivalent to the loss of SOC per unit of change in MAT reported here (table 7), if plant photosynthetic activity fails to sufficiently capture atmospheric $\mathrm{CO}_{2}$ into plant material, if sequestration of atmospheric $\mathrm{CO}_{2}$ back into sequestered SOC is inadequate, if soil moisture availability does not serve as an overriding influence during dry or warm periods of the year (Conant et al. 2004), and finally, if the rates of SOC decrease across the world's grasslands soils (3.7 billion ha [9.14 billion ac] of permanent pasture [Lal 2004]) are similar to those observed in this study for the US Great Plains, the potential resulting amounts of $\mathrm{CO}_{2}$ available to be released into the atmosphere would severely stress the ability of the earth's sinks to absorb the increased atmospheric loading resulting from SOC decomposition.

Similar to SOC, the rate of loss of SON across US Great Plains has a slope of about $-180 \mathrm{~kg} \mathrm{SON} \mathrm{ha}{ }^{-1}$ per $1^{\circ} \mathrm{C}\left(-160 \mathrm{lb} \mathrm{ac}^{-1}\right.$ per $1.8^{\circ} \mathrm{F}$ ) increase in MAT (figure $4 \mathrm{a}$ ). The loss of SON from the SOM pool into the soil 
matrix is controlled by the several processes of the $\mathrm{N}$-cycle wherein the $\mathrm{N}$ is mineralized to $\mathrm{NH}_{4}^{+}$and nitrified to $\mathrm{NO}_{3}^{-}$, both of which can be available for plant uptake. However, $\mathrm{NO}_{3}{ }^{-}$can be leached, $\mathrm{NH}_{4}{ }^{+}$can be volatilized, or either or both can occur during denitrification. Through other N-cycle processes, both forms can be transformed into nitrous oxide $\left(\mathrm{N}_{2} \mathrm{O}\right)$, a powerful greenhouse gas, as well. A rate of loss of $180 \mathrm{~kg}$ SON ha ${ }^{-1}$ (160 $\mathrm{lb} \mathrm{SON} \mathrm{ac}^{-1}$ ) (table 7 and figure $4 \mathrm{a}$ ) over a 30-year period would be about $6 \mathrm{~kg} \mathrm{~N} \mathrm{ha} \mathrm{N}^{-1}\left(5.3 \mathrm{lb} \mathrm{N} \mathrm{ac}^{-1} \mathrm{yr}^{-1}\right)$, an amount readily absorbed annually by growing plants or crops, but the amounts would still be large when estimated for the entire US Great Plains.

We have no data and are not able to include information about the effects of higher concentrations of atmospheric $\mathrm{CO}_{2}$ on either plant productivity or soil decomposition. However, the impacts of $\mathrm{CO}_{2}$ and temperature on SOC are likely mediated by their effects on soil water availability that in turn might regulate decomposition and plant productivity (Dijkstra and Morgan 2012; Morgan et al. 2011). Presently, C4 grasses are common in US Great Plains grasslands and might become more abundant with increasing temperature. However, Morgan et al. (2011) reported that C3 plants, with their $\mathrm{CO}_{2}$-limited photosynthetic metabolism, may become more competitive in future $\mathrm{CO}_{2}$-enriched rangelands. Research by McLauchlan et al. (2006) indicates that it may not be possible to manipulate the storage of SOC over long periods of time-at least in former agricultural fields - using C3 versus C4 grasses. Considerable uncertainty exists about which plant photosynthetic type will be favored under future, warmer, $\mathrm{CO}_{2}-$ enriched conditions. The relative abundances of these two photosynthetic types may govern spatial and temporal aspects of water and nutrient cycling, net primary production, and plant-animal interactions. The results by Morgan et al. (2011) illustrate that water conservation effects of elevated $\mathrm{CO}_{2}$ may cancel the desiccating effects of moderately warmer temperatures, but much uncertainty exists (Carrillo et al. 2011) about combined effects of climate warming, soil moisture, and increased atmospheric $\mathrm{CO}_{2}$. Despite potential increased plant input under elevated $\mathrm{CO}_{2}$ alone and in combination with warming, Parton et al. (2007) predicted that increased temperature will decrease total SOC.
There is also uncertainty as to the effect of warming and increased atmospheric $\mathrm{CO}_{2}$ on different SOM pools. Elevated levels of $\mathrm{CO}_{2}$ may possibly retard decay of resistant slow-turnover SOM while increasing the decomposition rate of labile fast-turnover SOM (Cardon et al. 2001). Other studies (de Graaff et al. 2009; Del Galdo et al. 2006; Liu et al. 2009) report elevated $\mathrm{CO}_{2}$ depletes both resistant SOM and C fractions derived from fresh plant material with effects of warming depending on the SOM pool examined, while soil drying may limit plant productivity and SOM decomposition.

The Role of Agricultural Management. In the context of climate change, it is essential that soil management practices constrain the loss of SOM and decrease the vulnerability of SOC and SON stocks to loss. Management practices to decrease PET, such as no-tillage or surface residue management that affect the MAP:PET ratio, might maintain or increase $\mathrm{kg} \mathrm{ha}^{-1}$ of SOC and SON (figures $3 \mathrm{~b}$ and $4 \mathrm{~b}$ ). However, if the MAP:PET ratio decreases with a decrease in MAP and/or with an increase in PET, a possibly negative effect on $\mathrm{kg} \mathrm{ha}^{-1}$ of SOC and SON could result. The clay is important for maintaining SOC and SON (table 7).A future climate (including drought, heat waves, or intense rainfall) resulting in conditions where fine soil particles (clay) and their associated SOM are lost by either wind or water erosion could decrease SOC and SON. Thus, conserving the SOC and SON in soil will require use of conservation practices to minimize soil erosion, maintain soil cover, and decrease PET while also increasing precipitation efficiency through use of best management practices, such as no-till, cover cropping, and crop rotations.

\section{Summary and Conclusions}

Across the US Great Plains, predicted longterm increases in temperature and increased variability in the timing and quantity of precipitation will likely result in a net loss of SOC and SON from these ecosystems. The combined effect is likely to be due to increased soil respiration from SOM decomposition and a decrease in plant productivity due to moisture constraints. We cannot address over what time period and to what soil depth a SOC and SON decrease might occur. Our estimates are incomplete because no estimates were made of the changes in amounts of SOC or SON below $10 \mathrm{~cm}$ (3.9 in), the effects of photosynthe- sis and cycling of photosynthetically fixed $\mathrm{C}$ back into SOC, the differences among SOM pools, or of the effects of elevated atmospheric $\mathrm{CO}_{2}$ on various plant and soil processes. Our data support the need for additional research along environmental gradients that are relevant to climate change. Supportive of our research is that Billings et al. (2012) are recently advocating collaborations of geochemists and ecosystem scientist to collect flux data across temporal and spatial scales to improve and refine predictions of SOM feedback to earth's C cycle.

Although the CRP program has sequestered substantial amounts of $\mathrm{C}$ and $\mathrm{N}$ compared to cropland, our data show that $\mathrm{C}$ and $\mathrm{N}$ stocks under all land uses (native prairie, CRP, and cropped) are equally vulnerable to increased temperature and decreased water availability. Based on empirical relationships, our data suggest that a $1^{\circ} \mathrm{C}\left(1.8^{\circ} \mathrm{F}\right)$ increase in MAT across the US Great Plains would result in the loss of $486 \mathrm{Tg}$ (536 million $\mathrm{tn}$ ) of SOC (1.78 Pg CO2e) (1.96 billion tn $\mathrm{CO}_{2} \mathrm{e}$ ) and $180 \mathrm{~kg} \mathrm{SON} \mathrm{ha}^{-1}(160 \mathrm{lb} \mathrm{SON}$ $\mathrm{ac}^{-1}$ ) from the top $10 \mathrm{~cm}$ (3.9 in) of soil over 30 years, assuming all else equal. Combined, increased temperature, along with land use conversion from CRP to cropped agriculture, may significantly decrease the existing SOC sink. However, management practices that minimize soil erosion and reduce evapotranspiration may help offset $\mathrm{C}$ and $\mathrm{N}$ loss in the US Great Plains.

\section{Acknowledgements}

This research was funded by the USDA Agricultural Research Service (ARS), including funds from the USDA ARS GRACEnet project and partly by the USDA Natural Resources Conservation Service (NRCS). Authors acknowledge the important technical contributions of Edward Buenger, physical science technician, Fort Collins, Colorado (retired); Susan Sampson-Liebig, soil scientist with the NRCS, Bismarck, North Dakota; and many student employees. Gratefully acknowledged is field coordination in the form of assistance by USDA, NRCS, and ARS personnel in several states where samples were collected as is the laboratory support provided by the USDA NRCS Soil Survey Laboratory (National Soil Survey Center).

\section{Disclaimer}

USDA is an equal opportunity provider and employer. Mention of trade names or commercial products in this publication is solely for the purpose of providing specific information and does not imply recommendation or endorsement by the USDA. 


\section{References}

Billings, S.A., S.E. Ziegler, W.H. Schlesinger, R. Benner, and D. de B. Richter. 2012. Predicting carbon cycle feedbacks to climate: Integrating the right tools for the job. EOS 93(19):188.

Blake, G.R., and K.H.Hartge. 1986. Bulk Density. In Methods of Soil Analysis, Part 1; Physical and Mineralogical Methods (2nd Ed), ed Arnold Klute, 363-375. Madison, WI: American Society of America, Soil Science Society of America.

Burke, I.C., C.M. Yonker, W.J. Parton, C.V. Cole, K. Flach, and D.S. Schimel. 1989. Texture, climate, and cultivation effects on soil organic matter content in US grassland soils. Soil Science Society of America Journal 53:800-805

Cardon Z.G., B.A. Hungate, C.A. Cambardella, F.S Chapin, C.B. Field, E.A. Holland, H.A. Mooney 2001. Contrasting effects of elevated $\mathrm{CO}_{2}$ on old and new soil carbon pools. Soil Biology and Biochemistry 33(3):365-37.

Carrillo, Y., E. Pendall, F.A. Dijkstra, J.A. Morgan, and J.M Newcomb. 2011. Response of soil organic matter pools to elevated $\mathrm{CO}_{2}$ and warming in a semi-arid grassland. Plant Soil 347:339-350.

Conant, R.T., P. Dalla-Betta, C.C. Klopatek, and J.M Klopatek. 2004. Controls on soil respiration in semiarid soils. Soil Biology and Biochemistry 36:945-951.

Conant R.T., M.G. Ryan, G.I. Ågren, H.E. Birge, E.A. Davidson, P.E. Eliasson, S.E. Evans, S.D. Frey, C.P. Giardina, F.M. Hopkins, R. Hyvönen, M.U.F. Kirschbaum, J.M. Lavallee, J. Leifeld, W.J. Parton, M.J. Steinweg, M.D. Wallenstein, J.Å. Wetterstedt, and M.A. Bradford. 2011. Temperature and soil organic matter decomposition rates - Synthesis of current knowledge and a way forward. Global Change Biology 17(11):3392-3404

de Graaff, M.A., C. Van Kessel, and J. Six. 2009 Rhizodeposition-induced decomposition increases $\mathrm{N}$ availability to wild and cultivated wheat genotypes under elevated $\mathrm{CO}_{2}$. Soil Biology and Biochemistry 41(6):1094-1103.

Del Galdo I., W.C. Oechel, and M.F. Cotrufo. 2006. Effects of past, present and future atmospheric $\mathrm{CO}_{2}$ concentrations on soil organic matter dynamics in a chaparral ecosystem. Soil Biology and Biochemistry 38(11):3235-3244.

Del Grosso, S.J., W.J. Parton, A.R. Mosier, E.A. Holland, E. Pendall, D.S. Schimel, and D.S. Ojima. 2005. Modeling soil $\mathrm{CO}_{2}$ emissions from ecosystems. Biogeochemistry 73:71-91.

Del Grosso, S.J., W.J. Parton, T. Stohlgren, D. Zheng, D. Bachelet, S. Prince, K. Hibbard, and R. Olson. 2008. Global potential net primary production predicted from vegetation class, precipitation, and temperature. Ecology 89:2117-2126.

Dijkstra, F.A., and J.A. Morgan. 2012. Elevated $\mathrm{CO}_{2}$ and Warming effects on soil carbon sequestration and greenhouse gas exchange in agroecosystems: A review. In Managing Agricultural Greenhouse Gases: Coordinated Agricultural Research through GRACEnet to Address our Changing Climate, ed. M.A. Liebig, A.J. Franzluebbers, and R.F. Follett, Chapter 27, In press. Waltham, MA: Academic Press.

Epstein, H.E., W.K. Lauenroth, I.C. Burke, and D.P. Coffin. 1996. Ecological responses of dominant grasses along two climatic gradients in the great plains of the United States. Journal of Vegetation Science 7:777-788.
Feller, C., and M.H. Beare. 1997. Physical control of soil organic matter dynamics in the tropics. Geoderma 79:69-116.

Follett, R.F. 2009. US agriculture's relationship to soil carbon. Journal of Soil and Water Conservation 64:(6)159A-165A, doi:10.2489/jswc.64.6.159A.

Follett, R.F., J.M. Kimble, S. Leavitt, and E. Pruessner. 2004. The potential use of soil C isotope analyses to evaluate paleoclimate. Soil Science 169:71-488.

Follett, R.F., J.M. Kimble, E.G. Pruessner, S. Samson-Liebig, and S. Waltman. 2009a. Soil Organic C Stocks with Depth and Land Use at Various US Sites, In Soil Science Society of America Special Publication \#57, eds. R. Lal and R.F. Follett, 29-46. Madison, WI: Soil Science Society of America.

Follett, R.F., E.A. Paul, S. W. Leavitt, A.D. Halvorson, D. Lyon, and G.A. Peterson. 1997. Carbon isotope ratios of Great Plains soils in wheat-fallow systems. Soil Science Society of America Journal 61:1068-1077.

Follett, R.F., and E.G. Pruessner. 2001. Interlaboratory carbon isotope measurements on five soils. In Assessment Methods of Soil Carbon, eds. R. Lal, J.M. Kimble, R.F. Follett, and B.A. Stewart, 185-192. Boca Raton: Lewis Publishers, Soil Survey Laboratory Staff.

Follett, R.F., S.E. Samson-Liebig, J.M. Kimble, E.G. Pruessner, and S.W. Waltman. 2001. Carbon sequestration under the Conservation Reserve Program in the historic grassland soils of the United States of America. In Soil Carbon Sequestration and the Greenhouse Effect, ed. R. Lal, p. 27-40. Soil Science Society of America Special Publication 57. Madison, WI: Soil Science Society of America.

Follett, R.F., G.A.Varvel, J.M. Kimble, and K.P.Vogel. 2009b. No-till corn after bromegrass: Effect on Soil C and Soil Aggregates. Agronomy Journal 101:261-268.

Hassink, J. 1997. The capacity of soils to preserve organic C and $\mathrm{N}$ by their association with clay and silt particles. Plant Soil 191:77-87.

Homann, P.S., J.S. Kapchinske, and A. Boyce. 2007. Relations of mineral-soil $\mathrm{C}$ and $\mathrm{N}$ to climate and texture: Regional differences within the conterminous USA. Biogeochemistry 85:303-316.

Jenny, H. 1941. Factors of Soil Formation, 1st ed. New York McGraw-Hill Book Company Inc.

Jobbagy,E.G., and R.B.Jackson.2000.The vertical distribution of soil organic carbon and its relation to climate and vegetation. Ecological Applications 10:423-436.

Kuchler, A.W. 1985. Potential natural vegetation. 1:750,000,000 scale map. Digital product. University of Kansas, 1966. National Atlas of the United States of America. Reston, VA: Department of the Interior, US Geological Survey.

Lal, R. 2004. Soil carbon sequestration impacts on global climate change and food security. Science 304:1623-1627.

Leavitt, S.W., R.F. Follett, J.M. Kimble, and E.G. Pruessner. 2007. Radiocarbon and $\delta 13 \mathrm{C}$ depth profiles of soil organic carbon in the US Great Plains: A possible spatial record of paleoenvironment and paleovegetation. Quaternary International 162-163(0):21-34.

Liebig, M., M. Schmer, K. Vogel and R. Mitchell, 2008. Soil carbon storage by switchgrass grown for bioenergy. BioEnergy Research 1(3):215-222.

Liu W.X., Z. Zhang, and S.Q. Wan. 2009. Predominant role of water in regulating soil and microbial respiration and their responses to climate change in a semiarid grassland. Global Change Biology 15(1):184-195.
McCulley, R.L., I.C. Burke, and W.K. Lauenroth. 2009. Conservation of nitrogen increases with precipitation across a major grassland gradient in the Central Great Plains of North America. Oecologia 159:571-581.

McLauchlan, K.K., S.E. Hobbie, and W.M. Post. 2006. Conversion from agriculture to grassland builds soil organic matter on decadal time scales. Ecological Applications 16:143-153.

Morgan, J.A., D.R. LeCain, E. Pendall, D.M. Blumenthal, B.A. Kimball,Y. Carrillo, D.G.Williams. 2011. C4 grasses prosper as carbon dioxide eliminates desiccation in warmed semi-arid grassland. Nature 476:202-205.

NRCS (Natural Resources Conservation Service). 2004. Soil Survey Laboratory methods manual. Soil Survey Investigations Report No. 42. Version 4.0, November 2004. Rebecca Burt (ed.) http://soils.usda. gov/technical/lmm/.

NCDC (National Climatic Data Center). 2002. National Climatic Data Center/NESDIS/NOAA, 2002. Climatography of the United States NO 81. Asheville, North Carolina. http://www.northwest-gardening. com/resources/climate/data/COnorm.pdf.

Parton, W., J. Morgan, D. Smith, S. Del Grosso, L. Prihodko, D. LeCain, R. Kelly, R., and S. Lutz. 2012. Impact of precipitation dynamics on net ecosystem productivity. Global Change Biology 18:915-927, doi: 10.1111/j.1365-2486.2011.02611.

Parton, W.J., J.A. Morgan, G.M. Wang, and S. Del Grosso. 2007. Projected ecosystem impact of the prairie heating and $\mathrm{CO}_{2}$ enrichment experiment. New Phytol 174(4):823-834.

Reimans, C., P. Filzmoser, R. Garrett, and R. Dutter. 2008. Statistical Data Analysis Explained: Applied Environmental Statistics with R. Hoboken, NJ: John Wiley \& Sons Ltd.

SAS. 2002 to 2008. SAS 9.2, Cary, NC: SAS Institute Inc.

Smith P., C. Fang, J.J.C. Dawson, and J.B. Moncrieff. 2008. Impact of global warming on soil organic carbon. Advances in Agronomy 97:1-43.

Snedecor, G.W., and W.G. Cochran. 1967. Statistical Methods, 6th ed.Ames, IA: Iowa State University Press.

US EPA (Environmental Protection Agency). 2010. Inventory of US Greenhouse Gas Emissions and Sinks. 1990-2008 Trends. Office of Atmospheric Programs (6207J). http://www.epa. gov/climatechange/emissions/usinventoryreport.html.

USDA FSA (USDA Farm Service Agency). 2009. Conservation Reserve Program. Annual Summary and Enrollment Statistics, ed. Alex Barbarika, Natural Resources Analysis Group, Economic and Policy Analysis Staff (EPAS), Farm Service Agency (FSA). http://www. fsa.usda.gov/Internet/FSA_File/fyannual2009.pdf, http://www.fsa.usda.gov/.

USGCRP (US Global Change Research Program). 2009. Global Climate Change Impacts in the US. Washington, DC: US Global Change Research Program. http://www.globalchange.gov/ what-we-do/assessment/previous-assessments/ global-climate-change-impacts-in-the-us-2009.

Vörösmarty, C. J., C.A. Federer, and A.L. Schloss. 1998. Potential evaporation functions compared on US watersheds: Possible implications for global-scale water balance and terrestrial ecosystem modeling. Journal of Hydrology 207:147-169. http://eos-webster.sr.unh. edu/data_guides/ghaas_usa_dg.jsp.

Wishart, D. 2004. The Great Plains Region. In Encyclopedia of the Great Plains, xiii-xviii. Lincoln: University of Nebraska Press. 